\title{
Do General Managerial Skills Spur Innovation?*
}

\author{
Cláudia Custódio \\ Arizona State University - W. P. Carey School of Business \\ claudia.custodio@asu.edu \\ Miguel A. Ferreira \\ Nova School of Business and Economics, ECGI \\ miguel.ferreira@novasbe.pt \\ Pedro Matos \\ University of Virginia - Darden School of Business, ECGI \\ matosp@darden.virginia.edu
}

This Version: July 2013

\begin{abstract}
We show that firms with chief executive officers (CEOs) that gather general managerial skills during their lifetime work experience produce more innovation. Firms with generalist CEOs invest more in R\&D and produce more patents than those with specialist CEOs. Generalist CEOs also create more diverse and original patent portfolios. We address the potential endogenous CEO-firm matching bias using firm fixed effects and the variation on the enforceability of non-competing agreements across states and time as an instrument for general managerial skills. Our findings suggest that generalist CEOs spur innovation because they have skills that can be applied elsewhere should risky innovation projects fail. We conclude that an efficient labor market for executives can promote corporate innovation by acting as mechanism of tolerance for failure.
\end{abstract}

JEL classification: G32, J24, O31

Keywords: General human capital, Innovation, Patents, R\&D, Risk taking

\footnotetext{
* We thank Heitor Almeida, Daniel Ferreira, Po-Hsuan Hsu, Dongmei Li, Elena Loutskina; and seminar participants at the University of Hong Kong for helpful comments. We are grateful to David Hirshleifer, Angie Low and Siew Hong Teoh for sharing data on proxies of CEO overconfidence.
} 


\section{Introduction}

Innovation is a driving force in today's economy but investing in new technologies, products or services is risky and challenging. Decisions on the research and development (R\&D) budget and the prioritization of research projects fall in the hands of top managers. But is the chief executive officers (CEOs) skill set an important determinant of corporate innovation? And which CEO skills are more valuable to produce innovation?

Managers draw on skills gathered throughout their careers when they make corporate decisions. Starting with Becker (1962), the literature has emphasized two types of managerial capital: general human capital (i.e., not specific to any organization and transferable across firms or industries) and firm-specific human capital (i.e., valuable only within an organization). In this paper, we test the hypothesis that CEOs with more general skills foster innovation. ${ }^{1}$

Innovation carries a significant risk for the CEO as there are inherent uncertainties from concept to actual firm profits. We conjecture that a generalist CEO is more likely to exploit innovative projects because he is less sensitive to the risk of being fired given his more diverse business experience versus a CEO with a focused professional experience. A generalist can move across industries more easily as a failure might not necessarily give a bad signal of his ability in other industries. Thus, the larger set of outside options of generalist CEOs versus specialist CEOs acts as a (labor) market mechanism of tolerance for failure that fosters innovation. This mechanism is an alternative to internal mechanisms such as CEO contracts offering long-term compensation plans and job security. Manso (2011) shows that the optimal incentive mechanism that motivates innovation rewards long term success but tolerates early failure. ${ }^{2}$

\footnotetext{
${ }^{1}$ Murphy and Zabojnik (2007) show that increases in external CEO hiring and executive compensation can be explained by the increased importance of general skills over the past decades.

2 Lerner and Wulf (2007), Francis, Hasan, and Sharma (2011), and Tian and Wang (2012) provide evidence consistent with this idea.
} 
Additionally, a generalist CEO may be better at "thinking out of the box", or bringing external knowledge to innovate in a field outside the company's current technological domain. A CEO that has worked in multiple positions, firms, and industries may accumulate general human capital that can be useful when a firm needs to invest in transformative change. For these reasons, we expect generalists to promote innovation, especially with a higher degree of originality and impact.

An alternative hypothesis is that specialist CEOs have more technical expertise to identify and promote innovation. Innovation tends to occur in highly specialized areas such as biotechnology and information technology where managers with an industry background may have an advantage. Managerial skills in the field of knowledge can make specialists more prone to invest in innovation, and better able to identify good projects. ${ }^{3}$ In fact, general managerial skills could be just "general and not unique" and could be obtained from outside providers such as consultants. Therefore, it is an empirical question which CEO skills (general or specialist) matter for the quantity and quality of corporate innovation.

We examine the link between CEOs' general human capital and corporate innovation using the panel of Standard and Poor's (S\&P) 1,500 firms over the period from 1993 to 2003. To measure general managerial skills, we use the General Ability Index (GAI) developed by Custódio, Ferreira, and Matos (2013) that captures five aspects of a CEO’s professional career: past number of (1) positions, (2) firms, and (3) industries in which a CEO worked; (4) whether the executive held a CEO position at a different company; and (5) whether the CEO worked for a conglomerate firm. The index of general managerial ability is the first factor of the principal components analysis of the five proxies.

\footnotetext{
3 If specialists are better at identifying good innovation projects, generalists may decide to diversify while innovating. This may be another reason why generalists produce more diverse innovation than specialists.
} 
We start by examining whether firms run by generalist CEOs invest more in innovation, as measured by $R \& D$ expenditures. We find that $R \& D$ is positively associated with the $G A I$ of the CEO. This is a first indication in favor the hypothesis that generalist CEOs invest more in innovation. However, the evidence based on R\&D is preliminary since more R\&D spending does not necessarily lead to more and better innovation.

In the main set of tests, we examine the productivity of a firm's research activities using patent-based metrics. We use the NBER patent database (Hall, Jaffe, and Trajtenberg (2001)) to measure the quantity and originality of a firm's research output. We measure innovative activity by the number of patents that each firm files in a given year. We find that generalist CEOs have significantly higher patent counts. A one standard deviation increase in $G A I$ is associated with an increase of $15 \%$ in patent counts. We also measure the impact of a firm's patents by counting the citations that each patent receives from subsequent patents. The results suggest that firms with generalist CEOs generate more citations counts. ${ }^{4}$ The effect is also important in economic terms: a one standard deviation increase in GAI is associated with a $16 \%$ increase in citation counts. The results are robust when we adjust the citation count by truncation bias using the methods proposed by Hall, Jaffe, and Trajtenberg (2001).

We study the effect of general managerial skills on the direction of a firm's innovation efforts in addition to the intensity. We find that firms with generalist CEOs hold more diverse portfolios of patents as proxied by the Herfindahl index of the patent portfolio (patents applied by the firm over the previous five years) across technological classes (Hirshleifer, Hsu, and Li (2012)). Moreover, they make use and produce more diverse patents. We find a positive relation between GAI and measures of the originality and generality of the portfolio of patents as

\footnotetext{
${ }^{4}$ Hall, Jaffe, and Trajtenberg (2005) show that patent citations are positively correlated with firm market value.
} 
indicated by a wider set of technology classes of patents cited and subsequent citing patents. Manso (2011) and Almeida, Hsu, and Li (2012) classify innovative strategies into exploitative (i.e., refine existing technologies) and exploratory (i.e., engage in a more risky search for new technologies that can transform their business). We find that generalist CEOs engage more in exploratory than exploitative strategies relative to specialist CEOs.

The findings are robust to the use of alternative econometric specifications (including Negative Binomial and Poisson regression models for count dependent variables) and the inclusion of many firm-level controls such as firm size, tangibility, stock returns, and institutional ownership (e.g., Aghion, Van Reenen, and Zingales (2013)). The findings are also robust to the inclusion of many CEO-level controls. ${ }^{5}$ Galasso and Simcoe (2010), and Hirshleifer, Low, and Teoh (2012), show that CEO's psychological biases such as overconfidence increase the willingness to take riskier projects. We therefore control for the options-based and media-based CEO confidence measures (Malmendier and Tate (2005)) in our tests. We also control for the CEO compensation structure (Coles, Daniel, and Naveen (2006) and Bereskin and Hsu (2012)), and other observable characteristics such as CEO education, age, and tenure (Barker and Mueller (2002)).

Our estimates may be biased due to endogenous matching between CEOs and firms. We use propensity score matching to compare firms run by generalists to otherwise similar firms run by specialists and we continue to find a significant difference in innovation output. However, unobserved firm or CEO variation may still be driving both innovation and general managerial ability. Therefore, we account for unobserved factors that are time invariant using firm and CEO

\footnotetext{
${ }^{5}$ More broadly, researchers have examined whether corporate outcomes are affected by CEO characteristics. Bertrand and Schoar (2003) show that individual manager fixed effects matter for investment and financial policies of firms. However, Fee, Hadlock and Pierce (2013) cast doubt on the methodology for identifying managerial style effects on policy choices. They argue that CEO turnover events are endogenous and that managerial "style changes" are anticipated by corporate boards at the time of the CEO selection decision.
} 
fixed effects. The results suggest that the estimates are not driven by a non-random assignment of generalist CEOs to firms, which is also correlated with innovation.

To test for a causal link from CEO human capital to innovation output we use instrumental variables methods. We use state-level labor laws on non-competing agreements as a source of exogenous variation in the generality of human capital of the CEO. Non-competing agreements are contracts that prevent a worker from joining or creating a competing company after ending an employment contract. The enforceability of these contracts varies across U.S. states and over time. We use the index on the enforceability of non-competing agreements of Garmaise (2009) as an instrument for GAI. We find the noncompetition enforcement index to be positively and significantly correlated with GAI, especially when firms are exposed to significant in-state competition. This is because the enforcement of non-competing agreements limits withinindustry mobility but enhances between-industry mobility, contributing to the accumulation of general managerial skills. The evidence suggests a casual effect from general managerial skills to innovation.

Overall, we conclude that an efficient labor market for executives can promote innovation by acting as mechanism of tolerance for failure. Generalist CEOs are more likely to exploit innovative growth opportunities because they have skills that can be applied elsewhere should risky innovation projects fail. Our findings highlight the importance of general human capital and managerial skills in a modern knowledge-based economy where innovation is a key determinant of corporate success.

\section{Data and measures}

Our sample consists of a panel of CEO-firm-years in the 1993-2003 period of Standard and Poor's (S\&P) 1,500 firms drawn from the EXECUCOMP database. We manually match the 
executives in EXECUCOMP who are identified as CEOs in each year with the BoardEx database to have data on their prior professional experience. We then match firms in BoardEx where CEOs worked in the past to Compustat (US firms) and Datastream (international firms) to obtain the standard industrial classification (SIC). We use information on all of CEO's past positions, including those in non-S\&P 1,500 firms. We use this data to create an index of the generality of the CEO’s human capital.

We use the NBER patent database (Hall, Jaffe, and Trajtenberg $(2001,2005)$ ) to measure innovation for the S\&P 1,500 firms. The patent data are from the 2006 edition of the NBER patent database, which provides a link to EXECUCOMP by GVKEY. We control for firm characteristics using accounting data from Compustat, stock returns data from CRSP, and institutional ownership data from the Thomson CDA/Spectrum 13F Holdings. Variable definitions are provided in Table A1 in the Appendix.

The sample consists of S\&P 1,500 firms in the intersection of EXECUCOMP, BoardEx, and the NBER patent database. Firms that operate in four-digit SIC industries without any filed patent in the sample period are excluded. Financial firms and utilities are also excluded. We restrict our sample to firm-years for which CEO-firm endogenous matching is likely to be less important, and for which CEOs are more likely to make an impact in the innovation process. Specifically, we exclude firm-year observations that correspond to CEO with less than five years in the top executive position (i.e., we exclude recently appointed CEOs). ${ }^{6}$ The final sample consists of 1,365 CEOs with GAI from 7,653 firm-year observations between 1993 and 2003. Variables are winsorized at the $1 \%$ level in both tails.

\footnotetext{
${ }^{6}$ In this way, our findings are more likely to be driven by a causal effect of CEO skills on innovation than solely by matching. In the Internet Appendix, we show that the results are robust when we use a two-year or three-year CEO tenure cutoff.
} 


\subsection{Measuring general managerial ability}

Our goal is to examine the effect of general managerial ability on corporate innovation output. We use the General Ability Index (GAI) of Custódio, Ferreira, and Matos (2013), which captures the generality of the CEO's human capital based on the CEO's lifetime work experience in publicly traded firms prior to his current CEO position. A CEO who worked in different organizational areas, for multiple firms, in different industries, in a conglomerate firm or has performed the CEO function previously has probably acquired more generic skills. The GAI of CEO $i$ in year $t$ is defined as:

$$
G A I_{i, t}=0.268 X 1_{i, t}+0.312 X 2_{i, t}+0.309 X 3_{i, t}+0.218 X 4_{i, t}+0.153 X 5_{i, t}
$$

where $X 1$ is the number of different positions that a CEO had during his career; $X 2$ is the number of firms where a CEO worked; $X 3$ is the number of industries at the four-digit SIC level where a CEO worked; $X 4$ is the a dummy variable that equals one if a CEO previously held a CEO position at another firm; and $X 5$ is a dummy variable that equals one if a CEO worked for a multi-division firm (i.e., reports more than one business segment). A CEO with a high GAI is likely to have acquired general skills that are transferable across firms and industries and also has more attractive outside options. The weights in equation (1) are obtained from extracting common components, using principal component analysis, from the five variables. Higher levels of general human capital are reflected in a higher value of the index. The index is standardized to have zero mean and a standard deviation of one.

A good example of a generalist executive is Louis Gerstner who was CEO/Chairman of IBM from 1993-2002. He started his career at McKinsey \& Company, had previously been CEO of RJR Nabisco and also held senior positions at American Express. He has one of the highest GAI scores in our sample. Gerstner was considered an outsider when he joined IBM but was largely 
credited with turning around IBM's business, while John Akers, his predecessor, was an IBM lifer and more immersed in its corporate culture. Under Gerstner, IBM stopped development of its own operating system, withdrew from the retail desktop PC market and focused on IT services where the tech industry was headed. Gerstner oversaw a decade where IBM produced a record-setting number of patents for any U.S. firm. ${ }^{7}$

\subsection{Measuring innovation}

The first measure of innovation we use in our tests is R\&D spending. This is an "inputoriented" measure of innovation. We use the ratio of R\&D expenditures to the book value of assets $(R \& D)$. Firm-years with missing $R \& D$ information are assigned a zero value.

Our main tests, though, are based on "output-oriented" measures of innovation based on patent counts and citations. Therefore, the second measure of innovation is the number of patent applications filed by a firm in a given year (Patents). A concern with the data is that patents are included in the database only if they are eventually granted and there is, on average, a two-year lag between application and grant date. Since the latest year available in the patent database is 2006, patents applied for in 2004 and 2005 may not show up in the database. As suggested by Hall, Jaffe, and Trajtenberg (2001), we end our sample period in 2003 and include year fixed effects in our regressions to address time truncation issues. ${ }^{8}$

The third measure of innovation is the total number of citations ultimately received by the set of patents that a firm applied for in a given year (Citations). Patent counts are an imperfect proxy of innovation success as patents vary widely in their technological and economic relevance

\footnotetext{
${ }^{7}$ Bloomberg, “IBM Granted Most U.S. Patents for 20th Straight Year” (January 10, 2013).

${ }^{8}$ Although we exclude firms operating in four-digit SIC industries with no patents, there are many firm-years with zero patents or zero citations. To see if the results are driven by the jump from zero patents to at least one patent, we rerun the tests deleting firm-years with zero patents or citations. The estimates are quantitatively and qualitatively similar for the number of patents but less precise for cite-weighted measures of patents.
} 
(Griliches, Hall, and Pakes (1987)). A common way to measure the relevance of a patent is its citation count which takes into account both the number of patents and the number of citations subsequently received from other patents. ${ }^{9}$ Hall, Jaffe, and Trajtenberg (2005) show that patent citations are positively related to firm value.

Patents created near the ending year of the sample period have less time to accumulate citations. Therefore, citations suffer from a time truncation bias due to the finite length of the sample in the patent database. We address this concern by adjusting the citation count of each patent in two alternative ways. The first adjustment consists of multiplying each patent's citation count is by the weighting index from Hall, Jaffe, and Trajtenberg (2001, 2005). The resulting variable, $Q$ Citations, is the sum of the adjusted patent citations across all patents applied for in each year. The second adjustment consists of scaling each patent's citation count by the average citation count of all patents in the same two-digit technology class and year. The resulting variable, TT Citations, is the sum of the adjusted citation count across all patents applied for in each year.

So far, the measures of innovation capture the intensity but not the direction of a firm's innovation efforts. To proxy for the diversity and complexity of a firm's activities we use the Herfindahl index of the number of patents in the firm's portfolio across two-digit technological classes (Hirshleifer, Hsu, and Li (2012)). The patent portfolio includes all patents applied by the firm over the previous five years. Because we want to capture the diversity of the patent portfolio we use one minus the Herfindahl index (Innovative Diversity). A high value for the Innovative Diversity variable indicates a lower concentration of the patent portfolio in terms of technological fields.

\footnotetext{
${ }^{9}$ We obtain similar results when we exclude self-citations.
} 
The second measure for the direction of a firm's innovation efforts is the technological search distance between a firm's new patents and its existing patent portfolio proposed by Chao, Lipson, and Loutskina (2012). We take the current distribution of the number of a firm's patents across two-digit technological classes and then measure the degree of difference between this distribution and the analogous distribution calculated for new patents and adjusted for the expected degree of knowledge spillovers between patent classes (i.e., adjusted for the “closeness" of patent classes). A higher Search Distance indicates higher complexity of a firm’s innovative activities.

Another aspect to the firm's innovative activities is the technological knowledge base encompassed by the patents. The first measure is one minus the Herfindahl index of the citations made by the patent portfolio based on two-digit technology classes as proposed by Hall, Jaffe, and Trajtenberg (2001). This index looks at backward citations made by the patent portfolio. A high Originality Index (lower concentration) indicates that patents cited belong to a wider set of technological classes. The second measure is one minus the Herfindahl index of the citations received by the patent portfolio based on two-digit technology classes. This index looks at forward citations of the patent portfolio to measure the impact of the firm's patent portfolio. A high Generality Index (lower concentration) indicates that firm's patents are cited by subsequent patents that belong to a wider range of fields.

The final set of measures examines a firm's innovation strategy. We classify firms' patent activity into exploratory and exploitative as proposed by Sorensen and Stuart (2000), Katila and Ahuja (2002), Benner and Tushman (2003) and Almeida, Hsu, and Li (2012). Firms focusing on their existing expertise fields are expected to produce more exploitative patents, while firms exploring new areas are expected to produce more exploratory patents. We construct proxies for 
exploitative and exploratory patents based on the extent to which a firm's new patents use existing versus new knowledge. A firm's existing knowledge consists of its previous patent portfolio and the set of patents that have been cited by the firm's patents filed over the past five years. A patent is categorized as exploitative if at least $80 \%(60 \%)$ of its citations are based on existing knowledge, and a patent is categorized as exploratory if at least $80 \%$ (60\%) of its citations are based on new knowledge (i.e., citations not in the firm's existing knowledge base). We then calculate the ratio of exploitative patents for a given firm-year as the number of exploitative patents filed in a given year divided by the number of all patents filed by the firm in the same year (Exploitative Ratio 80, Exploitative Ratio 60). The ratio of exploratory patents for a given firm-year is defined as the number of exploratory patents filed in a given year divided by the number of all patents filed by the firm in the same year (Exploratory Ratio 80, Exploratory Ratio 60). A higher ratio of exploitative patents suggests a more focused innovative strategy, while a higher ratio of exploratory patents suggests a more divergent innovative strategy.

\subsection{Other explanatory variables}

When explaining $\mathrm{R} \& \mathrm{D}$ or patents we include several firm characteristics as controls in the base model following Hall and Ziedonis (2001) and Aghion, Van Reenen, and Zingales (2013). Firm size is proxied by sales. Capital intensity is proxied by the ratio of net property, plant, and equipment (PPE) to sales. Innovative activities are affected by institutional holdings thereby we include the percentage of shares held by institutional investors. We also control for past stock performance in the base model.

Coles, Daniel, and Naveen (2006) show that the form of CEO incentives matters for firm risk taking. In additional tests, we include controls that take into account CEO incentives: CEO Delta, defined as the dollar change in a CEO's stock and option portfolio for a $1 \%$ change in 
stock price, and measures the CEO's incentives to increases in stock price; and CEO Vega, defined as the dollar change in a CEO's option holdings for a $1 \%$ change in stock return volatility, and measures the risk-taking incentives generated by the CEO’s option holdings. We calculate CEO Delta and CEO Vega values using the one-year approximation method of Core and Guay (2002).

Hirshleifer, Low, and Teoh (2012) show that overconfident CEOs invest more in innovation, so we include measures of CEO overconfidence as explanatory variables. The first overconfidence measure (CEO Confidence Options) uses data on option compensation following Malmendier and Tate (2005). This variable takes a value of one if a CEO postpones the exercise of vested options that are at least $67 \%$ in the money, and zero otherwise. The intuition is that it is optimal for risk-averse and undiversified executives to exercise their own-firm stock options early if the option is sufficiently in the money (Hall and Murphy (2002)). The second overconfidence measure (CEO Confidence Press) relies on keyword searches of the text of press articles in Factiva following Malmendier and Tate (2008). This variable takes a value of one when the number of "confident" articles for a CEO in Factiva is greater than the number of “cautious" articles, and zero otherwise. We also control for the total number of press mentions over the same period (Total Press Mention).

\section{General managerial ability and innovation}

In this section, we test the hypothesis that CEOs with more general ability spur innovation.

\subsection{Univariate tests}

Table 1 shows summary statistics for the scale, success and novelty of corporate innovation, CEO characteristics, and firm characteristics. The average firm in the sample has a R\&D-to- 
assets ratio $(R \& D)$ of $3.7 \%$, files 34 patents per year and subsequently receives 219 citations for its patents. It also engages more in exploratory than exploitative research: the average Exploratory Ratio is more than double the average Exploitative Ratio.

Table 2 compares sample means between specialists and generalists CEOs. A generalist CEO is defined as a top executive who has a $G A I$ above the median in a given year. Firms with generalist CEOs versus specialist CEOs invest $0.6 \%$ more of its assets in $R \& D$, file more than double the patents (48 versus 21) and these patents generate more than twice as many subsequent citations (304 versus 141). Firms with generalists also seem to produce more novel knowledge, as measured by the Innovative Diversity variable of a firm's patent portfolio and its Search distance. The Search Distance variable is $31 \%$ higher for generalists, while the Innovative Diversity variable is 53\% larger for generalists. The patents produced by generalists both make use and produce more general knowledge, as measured by the Originality Index and the Generality Index, which are about $40 \%$ higher for generalists versus specialists. Finally, firms with generalist CEOs seem to engage more both in exploratory and exploitative activities (albeit relatively more in exploratory) when compared to specialist CEOs.

The univariate tests suggest an economically meaningful difference in terms of innovation output by firms with generalist CEOs. At this stage, however, we cannot attribute these differences just to the general managerial ability of CEOs as other firm and CEO factors could explain these patterns.

\section{2. $R \& D$ expenditures}

Table 3 tests whether generalist CEOs spend more resources in innovation. The dependent variable in these regressions is R\&D expenditure divided by firm total assets, expressed as a percentage $(R \& D)$. The main independent variable of interest is the GAI. We control for 
industry-year pair fixed effects in columns (1) and (3), and for firm and year fixed effects in columns (2) and (4). Standard errors are clustered by firm to account for within-firm correlation. The industry-year fixed effects control for innovation shocks that are specific to a given industry and year. Firm fixed effects control for unobserved time invariant firm heterogeneity. Following Aghion, Van Reenen, and Zingales (2013), we introduce fixed effects into the models using the “pre-sample mean scaling” method first proposed by Blundell, Griffith, and Van Reenen (1999).

Essentially, we exploit the fact that we have a long pre-sample history on R\&D expenditures and patenting behavior (of up to 25 years per firm) to construct the pre-sample average of citeweighted patents. This can then be used as an initial condition to proxy for unobserved heterogeneity under certain conditions (in particular, the first moments of the variables must be stationary).

We find that $R \& D$ positively and significantly associated with the general ability of the CEO. A one standard deviation in $G A I$ is associated with an increase of more than $0.4 \%$ in $R \& D$. Given an average $R \& D$ of $3.7 \%$, this represents an increase of $11 \%$. The coefficients of the remaining control variables are in line with previous studies. Smaller firms and less capital intensive firms tend to spend more in $R \& D$.

\subsection{Patents filing and citations}

Table 4 examines the relation between filed patents and the general ability of CEOs. The dependent variable is the natural logarithm of one plus the number of patents (Patents) in a given year in the OLS regressions in columns (1)-(4). Due to the count-based nature of the patent data, Hall, Jaffe, and Trajtenberg (2001) recommend using count-based models such as the Negative Binomial as alternatives to the OLS regression model. We use the Negative Binomial regressions 
where the dependent variable is Patents (columns (5)-(8)). ${ }^{10}$ We use firm control variables and industry-year pair fixed effects in columns (1), (3), (5) and (7), whereas in columns (2), (4), (6) and (8) we use firm and year fixed effects using the "pre-sample mean scaling" method (Blundell, Griffith, and Van Reenen (1999)). ${ }^{11}$ Standard errors are clustered by firm to account for within-firm correlation.

We find that firms with generalist CEOs have higher patent counts. The estimates in column (2) indicate that a one-standard deviation increase in GAI is associated with an additional $16 \%$ in Patents. When we control for stock returns and institutional ownership in addition to firm size and tangibility in columns (3) and (4), we find that the effect of GAI on Patents is similar. The Negative Binomial regression estimates confirm the findings using the OLS regression.

In Table 5 we measure the success of innovation activity using the count of citations that the firm's patents receive from subsequent patents. The dependent in the OLS specifications in columns (1)-(4) is the natural logarithm of one plus citations count (Citations), and Citations in the Negative Binomial model in columns (5)-(8). Panel A shows the results using Citations, and Panels B and C show the results using Citations adjusted for truncation bias using two alternative methods (Q Citations and TT Citations).

The GAI coefficient is positive and significant. The OLS estimates in Panel A, columns (1)(4), suggest that a one-standard deviation increase in $G A I$ is associated with an increase in the citations of patents produced by a firm between $15 \%$ and $18 \%$. Using the Negative Binomial regression model in Panel A, columns (5)-(8), we obtain similar estimates. These results suggest that generalist CEOs produce more citations counts and the effect is both statistically and

\footnotetext{
${ }^{10}$ Different assumptions with respect to the properties of the error term generate different estimators. A Poisson model assumes the mean equals the variance, and a Negative Binomial model relaxes this assumption. In the Internet Appendix, we find consistent results using a Poisson regression model.

${ }^{11}$ Estimates using within-sample firm fixed effects and CEO fixed effects are similar for the number of patents, but are less precise for citation counts (cite-weighted measures of patents).
} 
economically important. Using the estimate in column (8), a one-standard deviation increase in GAI is associated with an increase in the number of citations of up to $25 \%$. Finally, we also obtain consistent estimates using the citation measures adjusted for truncation bias, Q Citation and TT Citations, in Panels B and C of Table 5. In short, we find a positive and significant relation between $G A I$ and citation counts, which are a measure of the success and effectiveness of innovation activities.

\subsection{Relatedness of innovation}

We now test the hypotheses that firms with generalist CEOs produce more novel innovation. Generalist CEOs have more outside options in the executive labor market, which can operate as a tolerance for failure mechanism. Thus, generalist CEOs are willing to take riskier growth opportunities. We also test if, while innovating, firms headed by generalist CEOs make use of a more diverse set of existing patents, and if the patents they produce are also cited by a more diverse set of technological classes.

To perform these tests we use the Innovative Diversity and Search Distance on firms' patent portfolio and new patents, as well as the Originality Index and Generality Index on the knowledge input and output in the firm's innovation process. We run OLS regressions with industry-year pair fixed effects and use the same set of controls as in the Tables 3-5. ${ }^{12}$

Table 6 shows the results. We find that firms with generalist CEOs tend to hold a more diversified portfolio of patents. A one-standard deviation increase in GAI is associated with an increase of 0.04 (column (1)) in Innovative Diversity. Column (3) shows that generalist CEOs are associated with a significant increase in Search Distance of 0.016. This implies that firms headed

\footnotetext{
${ }^{12}$ We do not use firm fixed effects for these tests because for the measures calculated with the patent portfolio over a five year period we do not have sufficient time series variation for each firm.
} 
by CEOs with general managerial skills are reaching out for new technologies, which are distant from their current patent portfolio.

The results in columns (5)-(8) using the Originality Index and the Generality Index suggest that firms with generalist CEOs not only hold more diverse portfolios of patents, but they also make use and produce a more diverse set of knowledge. The Originality Index (columns (5) and (6)) increases by about 0.04 for a one-standard deviation increase in GAI. The effect is similar in magnitude for the Generality Index (columns (7) and (8)).

\subsection{Innovation strategy}

Manso (2011) makes the distinction between exploratory and exploitative activities in the innovation process. We test the hypothesis that generalist CEOs are more willing to encourage innovation strategies that pursues both these objectives. Still, we conjecture that the effect should be more pronounced for exploratory activities, which are intrinsically more uncertain.

Table 7 shows the results. The dependent variables are the Exploratory Ratio 80 (60) and the Exploitative Ratio 80 (60). We run OLS regressions with industry-year pairs fixed effects. We find that the GAI coefficient is positive and significant for both the Exploratory Ratio and Exploitative Ratio dependent variables. However, the relation between general skills and innovation is more pronounced for exploratory than exploitative innovation. The coefficient of GAI in the Exploitative Ratio regressions is positive and significant, but smaller than in the Exploratory Ratio regressions.

Overall, the results are consistent with firms run by generalist CEOs producing more innovation because the top management has been exposed to different industries, firms and roles in the past. This might help them to promote the R\&D teams in the organization to "think out of the box" and bring solutions from other contexts to produce more original innovation. 


\section{Identification and additional results}

In this section, we address the econometric identification of the effect of GAI on corporate innovation. The concern is that previous estimates might be biased due to the endogeneity of the matching between the CEO types and firms. Specifically, there may be omitted factors correlated with both innovation and the generality of human capital of the CEO. Even though we included

firm-level controls and industry-year fixed effects in our previous tests, the GAI coefficient might still be biased. Firms who choose generalist CEOs may also be the type of firms that do more innovation. We have addressed this concern, at least partially, by including firm fixed effects to account for any unobservable firm characteristic that is time invariant. Given that our sample period encompasses only 11 years, the fixed effect estimator is quite effective controlling for firm level unobservable variables (as opposed, for instance, to including a firm fixed effect in a panel of 50 years, where these unobservable variables are likely change over those 50 years).

\subsection{Propensity score match}

To address the endogenous matching concerns, we first use propensity score matching to compare firms run by generalist CEOs (treatment group) with firms run by specialist CEOs (control group) with virtually no observable differences in firm and CEO characteristics. A generalist (specialist) CEO is defined as a CEO with a GAI above (below) the yearly median. We construct the control group of specialist CEOs using the nearest-neighbor method with scores given by a probit regression model of a dummy that takes the value of one for generalist CEOs and zero for specialist CEOs. The explanatory variables are firm characteristics (Sales, Leverage, Market-to-Book, ROA, Volatility, Diversification Dummy, Stock Return, Cash, CAPEX, Firm Age, R\&D) and CEO characteristics (CEO Tenure, CEO Age, External Hire Dummy, MBA Dummy, CEO-Chair Dummy) as well as industry-year dummies. 
Panel A of Table 8 reports the estimates of the probit regression model. CEOs with more accumulated general human capital tend to be older, appointed from outside the firm, hold a master of business administration (MBA) degree, and have a shorter tenure than specialist CEOs. As expected, we find that firms with generalist CEOs are bigger and more diversified. We also find that firms with generalist CEOs have higher cash holdings, lower capital expenditures (CAPEX) but invest more in $R \& D$.

Panel B of Table 8 reports the average treatment effect (ATT) estimates, which are consistent to those obtained using panel regressions. We find that firms with generalist CEOs produce $15 \%$ more patents that subsequently generate $26 \%$ more citations than firms with specialist CEOs. We also find that firms with generalist CEOs have a statistically higher Innovative Diversity. The propensity score matching results indicate that the non-random assignment of generalist CEOs to more innovative firms (at least based on observable firm and CEO characteristics) does not explain our main findings.

\subsection{Instrumental variable estimates}

Despite the battery of tests we run so far, we cannot conclude that causality runs from generalist managerial skills to corporate innovation. We use instrumental variables methods to further address this issue. We make use of non-competing agreements as an instrument for the generality of human capital of the CEO. Non-competing agreements are contracts that prevent a worker from joining or creating a competing company. Bishara, Martin, and Thomas (2013) report that non-competing clauses are frequent in CEO contracts (79\% of the contracts have this type clause in the 1993-2010 period) and there is a significant trend toward the use of noncompeting clauses in CEO contracts over time. The enforceability of these clauses exhibits both cross sectional (it varies across U.S. states) and time series variation (states adopt these at 
different times). ${ }^{13}$ We use the index on the enforceability of non-competing agreements (Enforcement Index) in Garmaise (2009),

A good instrument should be correlated with the endogenous variable (GAI), but not with the error term on the dependent variables of interest (innovation). We expect the Enforcement Index to be positively related with GAI since the enforcement of non-competing agreements limits within-industry transfers and enhances between-industry transfers, contributing to the accumulation of general managerial skills. Furthermore, there is a distinction between the exante effects of non-competing agreements (human capital investment) and the ex-post effects (labor mobility) as suggested by Posner, Triantis, and Triantis (2004). We expect executives to have an ex-ante incentive to accumulate more general skills in states with better enforcement of non-competing clauses. The idea is that if they anticipate the need of moving across industries they might decide to invest more in general skills rather than specific skills to have more outside options and facilitate ex-post mobility.

The enforceability of non-competing clauses is more difficult across states and typically has limited geographical scope. For this reason, we use the interaction of the Enforcement Index with the level of in-state competition following Garmaise (2009). We expect the effect of the Enforcement Index on GAI to be more pronounced when a firm is exposed to more intense instate competition. We define the In-State Competition variable as the fraction of total industry sales, excluding the own firm. We then use the interaction Enforcement Index $\times$ In-State Competition as an instrument for GAI.

The second important assumption of the instrumental variables method is that the instrument should be a variable that can be excluded from the list of variables affecting the variable of

\footnotetext{
${ }^{13}$ The cross sectional and time series variation of the instrument helps to rule out the concern that other state-level characteristics explain both $G A I$ and innovation.
} 
interest (innovation). Acharya, Baghai, and Subramanian (2012) find that stringent dismissal laws lead to greater innovation, but they find an insignificant association between the enforceability of non-competing agreements and patents. Moreover, Garmaise (2009) find no relation between the noncompetition enforcement index and R\&D.

Table 9 shows the results of the instrumental variables estimation for the Patents, Citations and Innovative Diversity variables. The regressions include the same control variables as in previous tables as well as firm and year fixed effects. The first stage regression also includes industry-year and state-year fixed effects.

Column (1) reports the first-stage regression estimates. We find that the Enforcement Index $\times$ In-State Competition coefficient is positively and significantly correlated with GAI. The effects of GAI on corporate innovation using instrumental variables methods are qualitatively and quantitatively similar to those in our main regressions tests, suggesting that the positive impact of general managerial skills on innovation is robust to endogeneity concerns.

Columns (2)-(6) present second-stage regression estimates. The effect of GAI on the number of filed patents is positive and significant. The effect of GAI on citations is also positive and this is also true when we adjust the citation measure for truncation bias. Finally, we also confirm that firms with generalist CEOs tend to hold more diversified portfolios of patents.

Overall, the results support a causal effect of the general ability of CEOs on firm innovation output. We find that increasing the generality of human capital of a CEO generates an increase in the number of filed patents and their success as measured by the number of citations.

\subsection{Additional controls}

A CEO's decision to support innovation activities is likely to be affected by his incentives to do so such as compensation packages. Panel A of Table 10 shows the results when we control for 
$\log (C E O$ Delta $)$ and $\log (C E O$ Vega $)$. We find very similar GAI coefficients to those in Tables 4-6. The signs of the coefficients of $\log (C E O$ Delta $)$ and $\log (C E O$ Vega $)$ are in line with those in Coles, Daniel, and Naveen (2006) and Hirshleifer, Low, and Teoh (2012). CEO Delta has a negative and significant coefficient, which suggests that more sensitive pay for stock performance is negatively associated with innovation. CEO Vega has the expected positive coefficient as a higher CEO Vega incentivizes risk taking but it is not statistically significant. Overall, the results show that the effect of general human capital on corporate innovation is not explained by differences in CEO pay contracts.

Hirshleifer, Low, and Teoh (2012) show that overconfident CEOs are more willing to invest in risky projects. An alternative explanation for our results may be that generalist CEOs, who are more mobile across firms and industries, are also more overconfident and this may explain why they are more innovative. Panels B and C of Table 10 shows the results of the regressions controlling for CEO Confidence Options and CEO Confidence Press. The effect of the CEO Confidence Press on innovation is positive and significant (Panel C), while the coefficient of the CEO Confidence Options is positive but insignificant in some specifications (Panel B). The estimated GAI coefficient does not change significantly from our baseline tests in Tables 4-6. We conclude that the overconfidence of CEOs and their general managerial ability are different mechanisms by which CEOs foster corporate innovation.

A potential concern with the interpretation of the results is that generalist CEOs might be matched to firms in more innovative industries. In previous tests we control for industry-year fixed effects, which relies only on within industry-year variation to estimate the effect of GAI and should therefore partially address this problem. In Table 11 we split our sample in innovative industries (if the average $Q$ Citations per patent for the industry in a given year is above the 
median) and non-innovative industries (if the average $Q$ Citations per patent for the industry in a given year is below the median) to further address this concern. We find that the positive relation between innovation and general managerial skills holds for innovative and non-innovative industries but is substantially stronger for innovative industries. This supports the idea that innovation by generalist CEO is not driven purely by the matching of generalist CEOs to firms in these industries.

Another concern we address is that generalist CEOs file more patents and have more citations simply because they spend more in R\&D. Table 12 replicates the results controlling directly for the level of R\&D expenditures (Panel A) or R\&D stock (Panel B). When we control for R\&D the effects of general ability of CEOs are slightly weaker, but we still find economically and statistically significant coefficient across all specifications, except for the TT Citations variable in Panel A. These tests show that the results on the relation between innovation and general managerial ability are not explained by generalist CEOs spending more in $\mathrm{R} \& \mathrm{D}$.

\subsection{Robustness checks}

In this section we report several robustness tests. The results are presented in the Internet Appendix. A possible interpretation of the patent citations results is that firms with generalist CEOs simply have more citations because they file more patents. We address this concern using measures of citations per patent, which assess the innovation success on a per-patent basis.

We have addressed concerns with omitted variable bias including several observable firm and CEO characteristics and using industry-year fixed effects or firm fixed effects in the regressions. We further control for firm characteristics (Volatility, Firm Age, Diversification Dummy, Board Size, Board Independence, Industry Sales Herfindahl, Governance Index) and 
CEO characteristics (CEO Tenure, CEO Age and MBA Dummy).

The tests so far use contemporaneous independent variables. We run alternative specifications where we lag the independent variables by one, two, or three years. We also estimate regressions using changes for both the dependent variable and explanatory variables that focus directly on whether changes on the GAI affect subsequently changes in innovation. The results on all these robustness checks confirm our main finding that generalist CEOs promote more and better quality innovation.

We also perform some robustness checks related to the construction of the GAI. We use a dummy variable that takes a value of one for generalist CEOs (i.e., top executives with a GAI above the median in a given year) instead of a continuous variable. We find that generalist CEOs produce $20 \%$ more patents and 26\% more citations than specialist CEOs. Finally, we run separate regressions for each individual component of the GAI. All individual components are

positively associated with innovation. The effect is stronger for the number of positions, number of firms, and number of industries.

\section{Conclusion}

We examine whether CEO general managerial skills matter for corporate innovation. We find that CEOs that gather more human capital through their lifetime work experience promote more and better innovation in the organizations that they run. Based on patent-based metrics, we find that generalist CEOs promote innovation in the form of patents with higher impact and more diversified patent portfolios. Generalist CEOs also incentivize firms to pursue more exploratory knowledge creation activities. We provide evidence consistent with a causal link from generality of CEOs human capital to the willingness to take risks using an instrument for general skills based on the state and time variation in the enforceability of non-competing agreements. 
Our findings support the idea that generalist executives push firms to exploit risky innovation opportunities. While specialist CEOs have skills valuable only within an organization, generalist CEOs have skills that can be applied elsewhere. Thus, generalist CEOs have more outside options, which act as labor market mechanism of tolerance for failure in alternative to internal mechanisms such as executive compensation plans. Given the growing importance of the knowledge-based economy, we give new insights into why general managerial skills command a compensation premium in the executive labor market. Future research should investigate how the growing importance of human capital can impact other corporate outcomes. 


\section{References}

Acharya, V., R. Baghai, and K. Subramanian, 2012, Wrongful discharge laws and innovation, Review of Financial Studies, forthcoming.

Aghion, P., J. Van Reenen, and L. Zingales, 2013, Innovation and institutional ownership, American Economic Review 103, 277-304.

Almeida, H., P. Hsu, and D. Li, 2012, When less is more: Financial constraints and innovative efficiency, Working paper, University of Illinois at Urbana-Champaign.

Barker, V., and G. Mueller, 2002, CEO characteristics and firm R\&D spending, Management Science 48, 782-801

Becker, G., 1962, Investment in human capital: a theoretical analysis, Journal of Political Economy 70, 9-49.

Benner, M., and M. Tushman, 2003, Exploitation, exploration, and process management: The productivity dilemma revisited, Academy of Management Review 28, 238-256.

Bereskin, F., and P. Hsu, 2012, New dogs new tricks: CEO turnover, CEO-related factors, and innovation performance, Working paper, University of Hong Kong.

Bertrand, M., and A., Schoar, 2003, Managing with style: The effect of managers on firm policies, Quarterly Journal of Economics 68, 1169-1208.

Bishara, N., K. Martin, and R. Thomas, 2013, When do CEOs have covenants not to compete in their employment contracts, Working paper, Vanderbilt University Law School.

Blundell, R., R. Griffith, and J. Van Reenen, 1999, Market shares, market value and innovation in a panel of British manufacturing firms, Review of Economic Studies 66, 529-554 
Chao, R., M. Lipson, and E. Loutskina, 2012, Financial distress and risky innovation, Working paper, University of Virginia, Darden School of Business.

Coles, J., N. Daniel, and L. Naveen, 2006, Managerial incentives and risk-taking, Journal of Financial Economics 79, 431-468.

Core, J., and W. Guay, 2002, Estimating the value of employee stock option portfolios and their sensitivities to price and volatility, Journal of Accounting Research 40, 613-630.

Custódio, C., M. Ferreira, and P. Matos, 2013, Generalists versus specialists: Lifetime work experience and chief executive officer pay, Journal of Financial Economics 108, 471-492.

Fee, E., C. Hadlock, J. Pierce, 2013, Managers with and without style: Evidence from exogenous CEO changes, Review of Financial Studies 26, 567-601.

Francis, B., I. Hasan, and Z. Sharma, 2011, Incentives and innovation: Evidence from CEO compensation contracts, Working paper, Fordham University.

Galasso, A., and T. Simcoe, 2010, CEO overconfidence and innovation, Working paper, University of Toronto.

Garmaise, M., 2009, Ties that truly bind: Non-competition agreements, executive compensation and firm investment, Journal of Law, Economics, and Organization 27, 376-425.

Griliches, Z., B. Hall, and A. Pakes, 1987, The value of patents as indicators of inventive activity, in Dasgupta and Stoneman (eds.), Economic Policy and Technological Performance, Cambridge: Cambridge University Press.

Hall, B., A. Jaffe, and M. Trajtenberg, 2001, The NBER patent citations data file: Lessons, insights and methodological tools, NBER Working paper 8498. 
Hall, B., A. Jaffe, and M. Trajtenberg, 2005, Market value and patent citations, RAND Journal of Economics 36, 16-38.

Hall, B., and K. J. Murphy, 2002. Stock options for undiversified executives, Journal of Accounting and Economics 33, 3-42.

Hall, B., and R. Ziedonis, 2001, The patent paradox revisited: an empirical study of patenting in the US semiconductor industry, 1979-1995, RAND Journal of Economics, 101-128.

Hirshleifer, D., P. Hsu, and D. Li, 2012. Don’t Hide Your Light Under a Bushel: Innovative Diversity and Stock Returns, Working paper, University of California at Irvine.

Hirshleifer, D., A. Low, and S. Teoh, 2012, Are overconfident CEOs better innovators? Journal of Finance 67, 1457-1498.

Katila, R., and G. Ahuja, 2002, Something old, something new: A longitudinal study of search behavior and new product introduction, Academy of Management Journal 45, 1183-1194.

Lerner, J., and J. Wulf, 2007, Innovation and incentives: Evidence from corporate R\&D, Review of Economics and Statistics 89, 634-644.

Malmendier, U., and G. Tate, 2005, CEO overconfidence and corporate investment, Journal of Finance 60, 2661-2700.

Malmendier, U., and G. Tate, 2008, Who makes acquisitions? CEO overconfidence and the market's reaction, Journal of Financial Economics 89, 20-43.

Manso, G., 2011, Motivating innovation, Journal of Finance 66, 1823-1869.

Murphy, K. J., and J. Zabojnik, 2007, Managerial capital and the market for CEOs, Working paper, University of Southern California. 
Posner, E., A. Triantis, and G. Triantis, 2004. Investing in human capital: The efficiency of covenants not to compete, Working paper, University of Virginia Law School.

Sorensen, J., and T. Stuart, 2000, Aging, obsolescence and organizational innovation, Administrative Science Quarterly 45, 81-112.

Tian, X., and T. Wang, 2012, Tolerance for failure and corporate innovation, Review of Financial Studies, forthcoming. 


\section{Table 1 \\ Summary Statistics}

This table presents the mean, median, standard deviation, minimum, maximum, and number of observations for each variable. The sample consists of EXECUCOMP firms for which chief executive officer (CEO) profile data are available from BoardEx and operate in the same four-digit SIC industries as the firms included in the NBER patent database in the 1993-2003 period. CEOs with tenure below five years are omitted. Financial and utility firms are omitted. All variables are winsorized at the $1^{\text {st }}$ and $99^{\text {th }}$ percentile values. Variable definitions are provided in Table A1 in the Appendix.

\begin{tabular}{|c|c|c|c|c|c|c|}
\hline & Mean & Median & $\begin{array}{c}\text { Standard } \\
\text { deviation }\end{array}$ & Minimum & Maximum & $\begin{array}{c}\text { Number of } \\
\text { observations }\end{array}$ \\
\hline \multicolumn{7}{|c|}{ Panel A: Innovation Measures } \\
\hline$R \& D$ & 0.037 & 0.009 & 0.058 & 0.000 & 0.271 & 7,649 \\
\hline Patents & 34.0 & 1.0 & 164.1 & 0.0 & 4,339.0 & 7,653 \\
\hline Citations & 219.1 & 0.0 & $1,390.2$ & 0.0 & $45,512.0$ & 7,653 \\
\hline Q Citations & 544.8 & 0.0 & $3,226.8$ & 0.0 & $104,792.0$ & 7,653 \\
\hline TT Citations & 16.6 & 0.0 & 80.0 & 0.0 & $2,038.1$ & 7,653 \\
\hline$Q$ Citations (per patent) & 7.0 & 0.0 & 13.0 & 0.0 & 265.4 & 7,653 \\
\hline TT Citations (per patent) & 0.322 & 0.000 & 0.668 & 0.000 & 12.987 & 7,653 \\
\hline Innovative Diversity & 0.348 & 0.359 & 0.344 & 0.000 & 0.941 & 7,653 \\
\hline Search Distance & 0.109 & 0.000 & 0.172 & 0.000 & 1.006 & 7,653 \\
\hline Originality Index & 0.427 & 0.540 & 0.358 & 0.000 & 0.945 & 7,653 \\
\hline Generality Index & 0.393 & 0.458 & 0.355 & 0.000 & 0.944 & 7,653 \\
\hline Exploitative Ratio 80 & 0.101 & 0.000 & 0.194 & 0.000 & 1.000 & 7,653 \\
\hline Exploitative Ratio 60 & 0.145 & 0.000 & 0.242 & 0.000 & 1.000 & 7,653 \\
\hline Exploratory Ratio 80 & 0.276 & 0.000 & 0.356 & 0.000 & 1.000 & 7,653 \\
\hline Exploratory Ratio 60 & 0.333 & 0.000 & 0.387 & 0.000 & 1.000 & 7,653 \\
\hline \multicolumn{7}{|c|}{ Panel B: CEO Characteristics } \\
\hline General Ability Index & -0.056 & -0.266 & 0.934 & -1.504 & 5.854 & 7,653 \\
\hline CEO Delta & 0.002 & 0.001 & 0.003 & 0.000 & 0.059 & 5,731 \\
\hline CEO Vega & 0.046 & 0.025 & 0.123 & 0.000 & 7.727 & 5,731 \\
\hline CEO Confidence Options & 0.669 & 1.000 & 0.471 & 0.000 & 1.000 & 6,919 \\
\hline CEO Confidence Press & 0.112 & 0.000 & 0.315 & 0.000 & 1.000 & 6,233 \\
\hline Total Press Mention & 3.6 & 0.0 & 14.8 & 0.0 & 360.0 & 6,233 \\
\hline \multicolumn{7}{|c|}{ Panel C: Firm Characteristics } \\
\hline Sales & $3,895.9$ & $1,092.1$ & $8,327.5$ & 26.6 & $56,877.0$ & 7,648 \\
\hline$P P E$ & 0.386 & 0.231 & 0.500 & 0.012 & 3.061 & 7,620 \\
\hline Stock Return & 0.183 & 0.112 & 0.526 & -0.775 & 2.208 & 6,978 \\
\hline Institutional Ownership & 0.611 & 0.632 & 0.190 & 0.000 & 1.319 & 7,498 \\
\hline
\end{tabular}




\section{Table 2}

\section{Innovation and General Managerial Ability: Univariate Tests}

This table presents the mean of innovation measures for the sample of generalist CEOs (those with General Ability Index above the yearly median) and specialist CEOs (those with General Ability Index above the yearly median), the associated difference and its $t$-statistic. The sample consists of EXECUCOMP firms for which chief executive officer (CEO) profile data are available from BoardEx and operate in the same four-digit SIC industries as the firms included in the NBER patent database in the 1993-2003 period. CEOs with tenure below five years are omitted. Financial and utility firms are omitted. Variable definitions are provided in Table A1 in the Appendix.

\begin{tabular}{lrrrr}
\hline & Generalist CEOs & Specialist CEOs & Difference & \multicolumn{1}{c}{-statistic } \\
\hline R\&D & 0.040 & 0.034 & 0.006 & 4.389 \\
Patents & 48.2 & 21.0 & 27.2 & 7.262 \\
Citations & 304.5 & 141.0 & 163.5 & 5.148 \\
Q Citations & 755.3 & 352.3 & 403.0 & 5.467 \\
TT Citations & 23.0 & 10.8 & 12.2 & 6.697 \\
Innovative Diversity & 0.424 & 0.278 & 0.146 & 18.953 \\
Search Distance & 0.124 & 0.095 & 0.029 & 7.449 \\
Originality Index & 0.499 & 0.362 & 0.137 & 17.072 \\
Generality Index & 0.467 & 0.325 & 0.142 & 17.890 \\
Exploitative Ratio 80 & 0.118 & 0.086 & 0.033 & 7.374 \\
Exploitative Ratio 60 & 0.170 & 0.122 & 0.048 & 8.682 \\
Exploratory Ratio 80 & 0.322 & 0.235 & 0.087 & 10.765 \\
Exploratory Ratio 60 & 0.390 & 0.281 & 0.109 & 12.384 \\
\hline
\end{tabular}




\section{R\&D Expenditures and General Managerial Ability}

This table presents estimates of ordinary least squares (OLS) panel regressions of the ratio of R\&D expenditures to total assets $(R \& D)$ on the General Ability Index and firm-level control variables. The sample consists of EXECUCOMP firms for which chief executive officer (CEO) profile data are available from BoardEx and operate in the same four-digit SIC industries as the firms included in the NBER patent database in the 1993-2003 period. CEOs with tenure below five years are omitted. Financial and utility firms are omitted. Regressions include industry-year dummies or year dummies in the case of the firm fixed effects model. Variable definitions are provided in Table A1 in the Appendix. Robust $t$-statistics adjusted for firm-level clustering are reported in brackets. ${ }^{*},{ }^{* * *}$, and ${ }^{* * * *}$ indicates significance at the $10 \%, 5 \%$ and $1 \%$ levels respectively.

\begin{tabular}{lcccc}
\hline & $(1)$ & $(2)$ & $(3)$ & $(4)$ \\
\hline General Ability Index & $0.424^{* * *}$ & $0.313^{* *}$ & $0.357^{* * *}$ & $0.276^{* *}$ \\
& {$[3.362]$} & {$[2.434]$} & {$[2.932]$} & {$[2.167]$} \\
Log (Sales) & $-0.653^{* * *}$ & $-0.718^{* * *}$ & $-0.580^{* * *}$ & $-0.651^{* * *}$ \\
& {$[-5.987]$} & {$[-6.556]$} & {$[-5.495]$} & {$[-6.057]$} \\
Log $(P P E)$ & 0.004 & $-0.264^{* *}$ & -0.021 & $-0.229^{* *}$ \\
& {$[0.032]$} & {$[-2.399]$} & {$[-0.165]$} & {$[-2.070]$} \\
Stock Return & & & 0.152 & $0.211^{* *}$ \\
& & & {$[1.354]$} & {$[2.080]$} \\
Institutional Ownership & & & $-1.227^{*}$ & -0.658 \\
& & & {$[-1.906]$} & {$[-1.119]$} \\
Firm fixed effects & No & Yes & No & Yes \\
Number of observations & 7,619 & 7,619 & 6,810 & 6,810 \\
R-squared & 0.466 & 0.473 & 0.463 & 0.465 \\
\hline
\end{tabular}




\section{Table 4 \\ Patent Counts and General Managerial Ability}

This table presents estimates of ordinary least squares (OLS) and Negative Binomial panel regressions of the number of patents (Patents) on the General Ability Index and firm-level control variables. The sample consists of EXECUCOMP firms for which chief executive officer (CEO) profile data are available from BoardEx and operate in the same four-digit SIC industries as the firms included in the NBER patent database in the 1993-2003 period. CEOs with tenure below five years are omitted. Financial and utility firms are omitted. Regressions include industry-year dummies or year dummies in the case of the firm fixed effects model. Variable definitions are provided in Table A1 in the Appendix. Robust $t$-statistics adjusted for firm-level clustering are reported in brackets. ${ }^{*},{ }^{* *}$, and ${ }^{* * *}$ indicates significance at the $10 \%, 5 \%$ and $1 \%$ levels respectively.

\begin{tabular}{|c|c|c|c|c|c|c|c|c|}
\hline & \multicolumn{4}{|c|}{ OLS } & \multicolumn{4}{|c|}{ Negative Binomial } \\
\hline & \multicolumn{4}{|c|}{ Log (Patents) } & \multicolumn{4}{|c|}{ Patents } \\
\hline & $(1)$ & $(2)$ & (3) & $(4)$ & (5) & (6) & $(7)$ & (8) \\
\hline General Ability Index & $\begin{array}{c}0.135^{* * *} \\
{[3.174]}\end{array}$ & $\begin{array}{c}0.160^{* * *} \\
{[3.625]}\end{array}$ & $\begin{array}{c}0.122 * * * \\
{[2.865]}\end{array}$ & $\begin{array}{c}0.150 * * * \\
{[3.305]}\end{array}$ & $\begin{array}{c}0.212 * * * \\
{[3.206]}\end{array}$ & $\begin{array}{c}0.248^{* * *} \\
{[3.006]}\end{array}$ & $\begin{array}{c}0.175^{* * *} \\
{[2.771]}\end{array}$ & $\begin{array}{c}0.222 * * * \\
{[2.762]}\end{array}$ \\
\hline Log (Sales) & $\begin{array}{c}0.514 * * * \\
{[14.729]}\end{array}$ & $\begin{array}{c}0.127 * * * \\
{[4.308]}\end{array}$ & $\begin{array}{c}0.539 * * * \\
{[14.878]}\end{array}$ & $\begin{array}{c}0.139 * * * \\
{[4.267]}\end{array}$ & $\begin{array}{c}0.771^{* * *} \\
{[16.558]}\end{array}$ & $\begin{array}{c}0.315^{* * *} \\
{[5.114]}\end{array}$ & $\begin{array}{l}0.807^{* * *} \\
{[17.131]}\end{array}$ & $\begin{array}{c}0.362 * * * \\
{[5.670]}\end{array}$ \\
\hline $\log (P P E)$ & $\begin{array}{c}0.181 * * * \\
{[4.515]}\end{array}$ & $\begin{array}{c}0.038 \\
{[1.187]}\end{array}$ & $\begin{array}{c}0.195 * * * \\
{[4.710]}\end{array}$ & $\begin{array}{c}0.055 \\
{[1.586]}\end{array}$ & $\begin{array}{c}0.378 * * * \\
{[4.821]}\end{array}$ & $\begin{array}{c}0.096 \\
{[1.025]}\end{array}$ & $\begin{array}{c}0.349 * * * \\
{[4.290]}\end{array}$ & $\begin{array}{c}0.123 \\
{[1.210]}\end{array}$ \\
\hline Stock Return & & & $\begin{array}{c}0.116^{* * *} \\
{[3.766]}\end{array}$ & $\begin{array}{c}0.177 * * * \\
{[5.580]}\end{array}$ & & & $\begin{array}{l}0.134 * * \\
{[2.284]}\end{array}$ & $\begin{array}{c}0.309 * * * \\
{[5.326]}\end{array}$ \\
\hline Institutional Ownership & & & $\begin{array}{c}-0.503^{* *} \\
{[-2.563]}\end{array}$ & $\begin{array}{c}0.134 \\
{[0.728]}\end{array}$ & & & $\begin{array}{c}-0.741^{* *} \\
{[-2.178]}\end{array}$ & $\begin{array}{c}-0.430 \\
{[-1.114]}\end{array}$ \\
\hline Firm fixed effects & No & Yes & No & Yes & No & Yes & No & Yes \\
\hline Number of observations & 7,619 & 7,619 & 6,810 & 6,810 & 7,619 & 7,619 & 6,810 & 6,810 \\
\hline R-squared & 0.430 & 0.440 & 0.450 & 0.444 & & & & \\
\hline
\end{tabular}




\section{Table 5 \\ Patent Citations and General Managerial Ability}

This table presents estimates of ordinary least squares (OLS) and Negative Binomial panel regressions of the number of citations (Citations) on the General Ability Index and firm-level control variables. The sample consists of EXECUCOMP firms for which chief executive officer (CEO) profile data are available from BoardEx and operate in the same four-digit SIC industries as the firms included in the NBER patent database in the 1993-2003 period. CEOs with tenure below five years are omitted. Financial and utility firms are omitted. Regressions include industry-year dummies or year dummies in the case of the firm fixed effects model. Variable definitions are provided in Table A1 in the Appendix. Robust $t$-statistics adjusted for firm-level clustering are reported in brackets. ${ }^{*},{ }^{* * *}$, and ${ }^{* * *}$ indicates significance at the $10 \%, 5 \%$ and $1 \%$ levels respectively.

\begin{tabular}{|c|c|c|c|c|c|c|c|c|}
\hline & \multicolumn{4}{|c|}{ OLS } & \multicolumn{4}{|c|}{ Negative Binomial } \\
\hline & \multicolumn{4}{|c|}{ Log (Citations) } & \multicolumn{4}{|c|}{ Citations } \\
\hline & (1) & (2) & (3) & (4) & (5) & (6) & (7) & (8) \\
\hline \multicolumn{9}{|c|}{ Panel A: Citations } \\
\hline \multirow[t]{2}{*}{ General Ability Index } & $0.174 * * *$ & $0.182 * * *$ & $0.150 * * *$ & $0.163 * * *$ & $0.255^{* * *}$ & $0.284^{* * *}$ & $0.188 * * *$ & $0.249 * * *$ \\
\hline & [3.177] & [3.244] & [2.775] & {$[2.856]$} & [3.298] & [3.064] & [2.592] & [2.814] \\
\hline \multirow[t]{2}{*}{ Log (Sales) } & $0.588 * * *$ & $0.124 * * *$ & $0.607 * * *$ & $0.133 * * *$ & $0.727 * * *$ & $0.201 * * *$ & $0.764 * * *$ & $0.246^{* * *}$ \\
\hline & [13.847] & [3.150] & [13.993] & [3.178] & [13.876] & [3.313] & [13.829] & [3.828] \\
\hline \multirow[t]{2}{*}{$\log (P P E)$} & $0.166^{* * *}$ & -0.007 & $0.183^{* * *}$ & 0.009 & $0.264 * * *$ & -0.116 & $0.238 * *$ & -0.118 \\
\hline & [3.191] & {$[-0.172]$} & [3.497] & {$[0.206]$} & {$[2.704]$} & {$[-1.056]$} & {$[2.286]$} & {$[-0.957]$} \\
\hline \multirow[t]{2}{*}{ Stock Return } & & & $0.174^{* * *}$ & $0.256^{* * *}$ & & & $0.267 * * *$ & $0.293^{* * *}$ \\
\hline & & & [3.944] & [5.812] & & & [3.740] & [4.305] \\
\hline \multirow[t]{2}{*}{ Institutional Ownership } & & & $-0.437 *$ & $0.400 *$ & & & $-0.923 * *$ & -0.111 \\
\hline & & & {$[-1.769]$} & [1.725] & & & {$[-2.186]$} & {$[-0.259]$} \\
\hline Firm fixed effects & No & Yes & No & Yes & No & Yes & No & Yes \\
\hline Number of observations & 7,619 & 7,619 & 6,810 & 6,810 & 7,619 & 7,619 & 6,810 & 6,810 \\
\hline R-squared & 0.446 & 0.448 & 0.477 & 0.462 & & & & \\
\hline \multicolumn{9}{|c|}{ Panel B: Citations $Q$} \\
\hline \multirow[t]{2}{*}{ General Ability Index } & $0.232 * * *$ & $0.249 * * *$ & $0.205^{* * *}$ & $0.229 * * *$ & $0.294 * * *$ & $0.309 * * *$ & $0.227 * * *$ & $0.272^{* * *}$ \\
\hline & [3.564] & [3.626] & [3.178] & [3.256] & [3.663] & [3.372] & [3.004] & [3.114] \\
\hline \multirow[t]{2}{*}{ Log (Sales) } & $0.683 * * *$ & $0.130 * * *$ & $0.711 * * *$ & $0.143^{* * *}$ & $0.717 * * *$ & $0.201^{* * *}$ & $0.756 * * *$ & $0.243^{* * *}$ \\
\hline & [13.906] & {$[2.771]$} & [14.025] & {$[2.815]$} & [13.791] & [3.315] & [13.780] & [3.809] \\
\hline \multirow[t]{2}{*}{$\log (P P E)$} & $0.194 * * *$ & -0.010 & $0.216 * * *$ & 0.011 & $0.257 * * *$ & -0.133 & $0.221 * *$ & -0.144 \\
\hline & [3.116] & {$[-0.195]$} & [3.397] & {$[0.205]$} & [2.597] & {$[-1.221]$} & [2.088] & {$[-1.170]$} \\
\hline \multirow[t]{2}{*}{ Stock Return } & & & $0.189 * * *$ & $0.274^{* * *}$ & & & $0.240 * * *$ & $0.295^{* * *}$ \\
\hline & & & [3.478] & [5.167] & & & [3.237] & [4.258] \\
\hline \multirow[t]{2}{*}{ Institutional Ownership } & & & $-0.527 *$ & 0.440 & & & $-1.286^{* * *}$ & -0.147 \\
\hline & & & {$[-1.722]$} & [1.496] & & & {$[-3.079]$} & {$[-0.352]$} \\
\hline Firm fixed effects & No & Yes & No & Yes & No & Yes & No & Yes \\
\hline Number of observations & 7,619 & 7,619 & 6,810 & 6,810 & 7,619 & 7,619 & 6,810 & 6,810 \\
\hline R-squared & 0.413 & 0.411 & 0.438 & 0.420 & & & & \\
\hline
\end{tabular}


Table 5: Continued

\begin{tabular}{lcccccccc}
\hline \multicolumn{10}{c}{ Panel C: Citations TT } \\
\hline General Ability Index & $0.094^{* *}$ & $0.114^{* * *}$ & $0.082^{* *}$ & $0.145^{* * *}$ & $0.189^{* * *}$ & $0.288^{* * *}$ & $0.127^{* *}$ & $0.269^{* * *}$ \\
& {$[2.475]$} & {$[3.135]$} & {$[2.124]$} & {$[3.612]$} & {$[2.662]$} & {$[3.305]$} & {$[1.989]$} & {$[3.011]$} \\
Log (Sales) & $0.408^{* * *}$ & $0.077^{* * *}$ & $0.431^{* * *}$ & $0.096^{* * *}$ & $0.622^{* * *}$ & $0.151^{* *}$ & $0.667^{* * *}$ & $0.251^{* * *}$ \\
& {$[13.318]$} & {$[3.254]$} & {$[13.389]$} & {$[3.346]$} & {$[13.317]$} & {$[2.532]$} & {$[13.612]$} & {$[4.007]$} \\
Log (PPE) & $0.130^{* * *}$ & -0.006 & $0.139^{* * *}$ & -0.002 & $0.223^{* *}$ & -0.121 & $0.208^{* *}$ & -0.155 \\
& {$[3.717]$} & {$[-0.254]$} & {$[3.798]$} & {$[-0.069]$} & {$[2.531]$} & {$[-1.130]$} & {$[2.228]$} & {$[-1.265]$} \\
Stock Return & & & $0.111^{* * *}$ & $0.131^{* * *}$ & & & $0.257^{* * *}$ & $0.290^{* * *}$ \\
& & & {$[3.609]$} & {$[4.312]$} & & & {$[3.635]$} & {$[4.262]$} \\
Institutional Ownership & & & $-0.445^{* * *}$ & 0.035 & & & $-1.104^{* * *}$ & -0.181 \\
& & & {$[-2.602]$} & {$[0.219]$} & & & {$[-2.695]$} & {$[-0.431]$} \\
Firm fixed effects & No & Yes & No & Yes & No & Yes & No & Yes \\
Number of observations & 7,619 & 7,619 & 6,810 & 6,810 & 7,619 & 7,619 & 6,810 & 6,810 \\
R-squared & 0.382 & 0.433 & 0.404 & 0.386 & & & & \\
\hline
\end{tabular}




\section{Table 6}

\section{Innovation Diversity, Originality and Generality and General Managerial Ability}

This table presents estimates of ordinary least squares (OLS) panel regressions of the patent portfolio diversity (Innovative Diversity and Search Distance) and originality and generality (Originality Index and Generality Index) on the General Ability Index and firm-level control variables. The sample consists of EXECUCOMP firms for which chief executive officer (CEO) profile data are available from BoardEx and operate in the same four-digit SIC industries as the firms included in the NBER patent database in the 1993-2003 period. CEOs with tenure below five years are omitted. Financial and utility firms are omitted. Regressions include industry-year dummies. Variable definitions are provided in Table A1 in the Appendix. Robust $t$-statistics adjusted for firm-level clustering are reported in brackets. ${ }^{*},{ }^{* *}$, and ${ }^{* * *}$ indicates significance at the $10 \%$, $5 \%$ and $1 \%$ levels respectively.

\begin{tabular}{|c|c|c|c|c|c|c|c|c|}
\hline & \multicolumn{2}{|c|}{ Innovative Diversity } & \multicolumn{2}{|c|}{ Search Distance } & \multicolumn{2}{|c|}{ Originality Index } & \multicolumn{2}{|c|}{ Generality Index } \\
\hline & (1) & $(2)$ & (3) & (4) & (5) & (6) & (7) & (8) \\
\hline \multirow[t]{2}{*}{ General Ability Index } & $0.041^{* * *}$ & $0.040 * * *$ & $0.016 * * *$ & $0.015^{* * *}$ & $0.040^{* * *}$ & $0.038 * * *$ & $0.041^{* * *}$ & $0.040 * * *$ \\
\hline & [4.727] & [4.523] & [3.884] & [3.582] & {$[4.480]$} & [4.143] & [4.675] & {$[4.456]$} \\
\hline \multirow[t]{2}{*}{ Log (Sales) } & $0.067 * * *$ & $0.068 * * *$ & -0.002 & -0.002 & $0.059 * * *$ & $0.060 * * *$ & $0.062 * * *$ & $0.064 * * *$ \\
\hline & [12.758] & [12.374] & {$[-0.845]$} & {$[-0.966]$} & [11.155] & [10.963] & [11.384] & [11.404] \\
\hline \multirow[t]{2}{*}{$\log (P P E)$} & $0.022 * * *$ & $0.027 * * *$ & -0.003 & -0.001 & $0.016^{*}$ & $0.020 * *$ & $0.017^{*}$ & $0.022 * *$ \\
\hline & {$[2.633]$} & [3.101] & {$[-0.729]$} & {$[-0.201]$} & [1.748] & [2.208] & [1.950] & [2.347] \\
\hline \multirow[t]{2}{*}{ Stock Return } & & 0.001 & & -0.002 & & -0.006 & & -0.003 \\
\hline & & [0.207] & & {$[-0.591]$} & & {$[-0.852]$} & & {$[-0.507]$} \\
\hline \multirow[t]{2}{*}{ Institutional Ownership } & & -0.030 & & -0.001 & & -0.048 & & $-0.096 * *$ \\
\hline & & {$[-0.729]$} & & {$[-0.054]$} & & {$[-1.112]$} & & {$[-2.293]$} \\
\hline Observations & 7,619 & 6,810 & 7,619 & 6,810 & 7,619 & 6,810 & 7,619 & 6,810 \\
\hline R-squared & 0.367 & 0.376 & 0.075 & 0.074 & 0.362 & 0.372 & 0.353 & 0.367 \\
\hline
\end{tabular}




\section{Table 7 \\ Innovation Strategy and General Managerial Ability}

This table presents estimates of ordinary least squares (OLS) panel regressions of innovation strategies (Exploratory Ratio and Exploitative Ratio) on the General Ability Index and firm-level control variables. The sample consists of EXECUCOMP firms for which chief executive officer (CEO) profile data are available from BoardEx and operate in the same four-digit SIC industries as the firms included in the NBER patent database in the 1993-2003 period. CEOs with tenure below five years are omitted. Financial and utility firms are omitted. Regressions include industry-year dummies. Variable definitions are provided in Table A1 in the Appendix. Robust $t$-statistics adjusted for firm-level clustering are reported in brackets. ${ }^{*},{ }^{* *}$, and ${ }^{* * *}$ indicates significance at the $10 \%, 5 \%$ and $1 \%$ levels respectively.

\begin{tabular}{|c|c|c|c|c|c|c|c|c|}
\hline & \multicolumn{2}{|c|}{ Exploratory Ratio 80} & \multicolumn{2}{|c|}{ Exploratory Ratio 60} & \multicolumn{2}{|c|}{ Exploitative Ratio 80} & \multicolumn{2}{|c|}{ Exploitative Ratio 60} \\
\hline & $(1)$ & (2) & (3) & (4) & $(5)$ & $(6)$ & $(7)$ & $(8)$ \\
\hline General Ability Index & $\begin{array}{c}0.031^{* * *} \\
{[4.005]}\end{array}$ & $\begin{array}{c}0.029 * * * \\
{[3.673]}\end{array}$ & $\begin{array}{c}0.035 * * * \\
{[4.113]}\end{array}$ & $\begin{array}{c}0.033 * * * \\
{[3.757]}\end{array}$ & $\begin{array}{c}0.012 * * * \\
{[3.043]}\end{array}$ & $\begin{array}{c}0.011^{* * *} \\
{[2.647]}\end{array}$ & $\begin{array}{c}0.016 * * * \\
{[3.082]}\end{array}$ & $\begin{array}{c}0.014 * * * \\
{[2.742]}\end{array}$ \\
\hline Log (Sales) & $\begin{array}{c}0.023^{* * *} \\
{[5.417]}\end{array}$ & $\begin{array}{c}0.022^{* * *} \\
{[5.146]}\end{array}$ & $\begin{array}{c}0.035 * * * \\
{[7.456]}\end{array}$ & $\begin{array}{c}0.034^{* * *} \\
{[7.111]}\end{array}$ & $\begin{array}{c}0.012 * * * \\
{[3.667]}\end{array}$ & $\begin{array}{c}0.014 * * * \\
{[4.323]}\end{array}$ & $\begin{array}{c}0.021^{* * * *} \\
{[5.031]}\end{array}$ & $\begin{array}{c}0.024^{* * * *} \\
{[5.779]}\end{array}$ \\
\hline $\log (P P E)$ & $\begin{array}{c}-0.003 \\
{[-0.516]}\end{array}$ & $\begin{array}{c}-0.001 \\
{[-0.132]}\end{array}$ & $\begin{array}{c}-0.003 \\
{[-0.449]}\end{array}$ & $\begin{array}{c}-0.001 \\
{[-0.118]}\end{array}$ & $\begin{array}{c}0.011^{* * *} \\
{[3.121]}\end{array}$ & $\begin{array}{c}0.012^{* * *} \\
{[3.212]}\end{array}$ & $\begin{array}{c}0.015^{* * * *} \\
{[3.133]}\end{array}$ & $\begin{array}{c}0.016^{* * *} \\
{[3.153]}\end{array}$ \\
\hline Stock Return & & $\begin{array}{c}0.011 \\
{[1.294]}\end{array}$ & & $\begin{array}{c}0.012 \\
{[1.342]}\end{array}$ & & $\begin{array}{c}0.001 \\
{[0.116]}\end{array}$ & & $\begin{array}{c}-0.000 \\
{[-0.071]}\end{array}$ \\
\hline Institutional Ownership & & $\begin{array}{c}-0.004 \\
{[-0.116]}\end{array}$ & & $\begin{array}{c}-0.005 \\
{[-0.130]}\end{array}$ & & $\begin{array}{c}-0.027 \\
{[-1.268]}\end{array}$ & & $\begin{array}{c}-0.040 \\
{[-1.509]}\end{array}$ \\
\hline Observations & 7,619 & 6,810 & 7,619 & 6,810 & 7,619 & 6,810 & 7,619 & 6,810 \\
\hline R-squared & 0.148 & 0.148 & 0.195 & 0.198 & 0.124 & 0.128 & 0.145 & 0.152 \\
\hline
\end{tabular}




\section{Table 8}

\section{Innovation and General Managerial Ability: Propensity Score Matching}

This table presents estimates of difference in the number of patents (Patent), number of citations (Citation), and innovation diversity (Innovative Diversity) between the treatment group (generalist CEOs) and the control group (specialist CEOs). The matched sample is constructed using a nearest-neighbor propensity score match with scores given by a probit model in which the dependent variable is a dummy that takes the value of one if a CEO has a General Ability Index above the median in a given year. The sample consists of EXECUCOMP firms for which chief executive officer (CEO) profile data are available from BoardEx and operate in the same four-digit SIC industries as the firms included in the NBER patent database in the 1993-2003 period. CEOs with tenure below five years are omitted. Financial and utility firms are omitted. Variable definitions are provided in Table A1 in the Appendix. Robust $t$-statistics adjusted for firm-level clustering are reported in brackets. ${ }^{*},{ }^{* *}$, and ${ }^{* * *}$ indicates significance at the $10 \%, 5 \%$ and $1 \%$ levels respectively.

\begin{tabular}{|c|c|}
\hline \multicolumn{2}{|c|}{ Panel A: Probit (Generalist Dummy) } \\
\hline \multirow[t]{2}{*}{ CEO Tenure } & $-0.038 * * *$ \\
\hline & {$[-13.290]$} \\
\hline \multirow[t]{2}{*}{ CEO Age } & $0.033^{* * *}$ \\
\hline & [11.469] \\
\hline \multirow[t]{2}{*}{ External Hire Dummy } & $0.309 * * *$ \\
\hline & [7.636] \\
\hline \multirow[t]{2}{*}{ MBA Dummy } & $0.432 * * *$ \\
\hline & [11.126] \\
\hline \multirow[t]{2}{*}{ CEO-Chair Dummy } & $0.403^{* * *}$ \\
\hline & [9.772] \\
\hline \multirow[t]{2}{*}{ Log (Sales) } & $0.204^{* * *}$ \\
\hline & [12.616] \\
\hline \multirow[t]{2}{*}{ Leverage } & 0.159 \\
\hline & [1.310] \\
\hline \multirow[t]{2}{*}{ Market-to-Book } & -0.016 \\
\hline & {$[-0.894]$} \\
\hline \multirow[t]{2}{*}{$R O A$} & $-0.744 * * *$ \\
\hline & {$[-2.845]$} \\
\hline \multirow[t]{2}{*}{ Volatility } & -0.166 \\
\hline & {$[-0.445]$} \\
\hline \multirow[t]{2}{*}{ Diversification Dummy } & $0.214^{* * *}$ \\
\hline & [5.032] \\
\hline \multirow[t]{2}{*}{ Stock Return } & 0.013 \\
\hline & [0.329] \\
\hline \multirow[t]{2}{*}{ Cash } & $0.307 * *$ \\
\hline & [1.981] \\
\hline \multirow[t]{2}{*}{ CAPEX } & $-1.124 * *$ \\
\hline & {$[-2.528]$} \\
\hline \multirow[t]{2}{*}{ Firm Age } & 0.000 \\
\hline & {$[0.278]$} \\
\hline \multirow[t]{2}{*}{$R \& D$} & $1.855^{* * *}$ \\
\hline & [3.845] \\
\hline Observations & 5,795 \\
\hline
\end{tabular}

Panel B: Average Treatment Effect (ATT)

\begin{tabular}{cccccc}
\hline & Log $($ Patents $)$ & Log $($ Citations $)$ & Log $($ Q Citations) & Log (TT Citations) & Innovative Diversity \\
\cline { 2 - 6 } & $(1)$ & $(2)$ & $(3)$ & $(4)$ & $(5)$ \\
\hline \multirow{2}{*}{ ATT } & $0.149^{* *}$ & $0.256^{* * *}$ & $0.309^{* * *}$ & 0.086 & $0.053^{* * *}$ \\
& {$[2.140]$} & {$[2.720]$} & {$[2.760]$} & {$[1.440]$} & {$[3.920]$} \\
\hline
\end{tabular}




\section{Table 9}

\section{Innovation and General Managerial Ability: Instrumental Variables}

This table presents estimates of instrumental variables methods using two-stage least squares (2SLS) panel regressions of the number of patents (Patents), number of citations (Citations), and innovation diversity (Innovative Diversity) on the General Ability Index and firm-level control variables. The sample consists of EXECUCOMP firms for which chief executive officer (CEO) profile data are available from BoardEx and operate in the same four-digit SIC industries as the firms included in the NBER patent database in the 1993-2003 period. CEOs with tenure below five years are omitted. Financial and utility firms are omitted. First-stage regressions include state-year and industry-year dummies. Second stage regressions include year dummies. Variable definitions are provided in Table A1 in the Appendix. Robust $t$-statistics adjusted for firm-level clustering are reported in brackets. ${ }^{*}, *$, and ${ }^{* * *}$ indicates significance at the $10 \%, 5 \%$ and $1 \%$ levels respectively.

\begin{tabular}{|c|c|c|c|c|c|c|}
\hline & $(1)$ & $(2)$ & (3) & $(4)$ & (5) & $(6)$ \\
\hline & $\begin{array}{c}\text { First Stage: } \\
\text { General } \\
\text { Ability Index }\end{array}$ & $\begin{array}{c}\text { Log } \\
\text { (Patents) }\end{array}$ & $\begin{array}{c}\log \\
\text { (Citations) }\end{array}$ & $\begin{array}{l}\text { Second Stage: } \\
\text { Log } \\
\text { (Q Citations) }\end{array}$ & $\begin{array}{c}\log \\
\text { (TT Citations) }\end{array}$ & $\begin{array}{c}\text { Innovative } \\
\text { Diversity }\end{array}$ \\
\hline \multirow[t]{2}{*}{ General Ability Index } & & $0.799 * * *$ & $0.764 * * *$ & $1.021^{* * *}$ & $0.549 * * *$ & $0.282 * * *$ \\
\hline & & [6.379] & [4.849] & {$[5.312]$} & {$[5.566]$} & [7.716] \\
\hline \multirow[t]{2}{*}{ Log (Sales) } & $0.174 * * *$ & 0.048 & 0.049 & 0.031 & 0.021 & 0.010 \\
\hline & {$[20.00]$} & [1.279] & [1.078] & [0.568] & {$[0.726]$} & [1.008] \\
\hline \multirow[t]{2}{*}{$\log (P P E)$} & $0.055^{* * *}$ & 0.041 & -0.001 & -0.003 & -0.011 & 0.010 \\
\hline & [4.230] & {$[1.051]$} & {$[-0.028]$} & {$[-0.049]$} & {$[-0.352]$} & [0.831] \\
\hline \multirow[t]{2}{*}{ Stock Return } & -0.022 & $0.192 * * *$ & $0.272 * * *$ & $0.293 * * *$ & $0.157 * * *$ & 0.010 \\
\hline & {$[-0.920]$} & {$[5.378]$} & {$[5.824]$} & [5.204] & [5.013] & [1.133] \\
\hline \multirow[t]{2}{*}{ Institutional Ownership } & $0.221 * * *$ & -0.042 & 0.246 & 0.235 & -0.016 & -0.065 \\
\hline & [3.450] & {$[-0.198]$} & [0.967] & {$[0.728]$} & {$[-0.096]$} & {$[-1.150]$} \\
\hline \multirow{2}{*}{ Enforcement Index $\times$ In-State Competition } & $0.074 * *$ & & & & & \\
\hline & {$[2.010]$} & & & & & \\
\hline \multirow{2}{*}{ In-State Competition } & 0.124 & & & & & \\
\hline & {$[0.960]$} & & & & & \\
\hline Firm fixed effects & Yes & Yes & Yes & Yes & Yes & Yes \\
\hline Observations & 6,777 & 6,777 & 6,777 & 6,777 & 6,777 & 6,777 \\
\hline
\end{tabular}




\section{Table 10 \\ Innovation and General Managerial Ability: Controlling for CEO Delta, Vega and Overconfidence}

This table presents estimates of ordinary least squares (OLS) panel regressions of the number of patents (Patents), number of citations (Citations), and innovation diversity (Innovative Diversity) on the General Ability Index and other CEO- and firm-level control variables. The sample consists of EXECUCOMP firms for which chief executive officer (CEO) profile data are available from BoardEx and operate in the same four-digit SIC industries as the firms included in the NBER patent database in the 19932003 period. CEOs with tenure below five years are omitted. Financial and utility firms are omitted. The regressions include the same firm-level control variables as in Table 4 (coefficients not shown). Regressions also include industry-year dummies. Variable definitions are provided in Table A1 in the Appendix. Robust $t$-statistics adjusted for firm-level clustering are reported in brackets. ${ }^{*}, *$, and ${ }^{* * *}$ indicates significance at the $10 \%, 5 \%$ and $1 \%$ levels respectively.

\begin{tabular}{|c|c|c|c|c|c|}
\hline & Log (Patents) & $\begin{array}{c}\log \\
\text { (Citations) }\end{array}$ & $\begin{array}{c}\log \\
\text { (Q Citations) }\end{array}$ & $\begin{array}{c}\text { Log } \\
\text { (TT Citations) }\end{array}$ & $\begin{array}{c}\text { Innovative } \\
\text { Diversity }\end{array}$ \\
\hline & $(1)$ & $(2)$ & (3) & $(4)$ & $(5)$ \\
\hline \multicolumn{6}{|c|}{ Panel A: Controlling for CEO Delta and CEO Vega } \\
\hline General Ability Index & $\begin{array}{c}0.149 * * * \\
{[3.291]}\end{array}$ & $\begin{array}{c}0.196 * * * \\
{[3.400]}\end{array}$ & $\begin{array}{c}0.263 * * * \\
{[3.829]}\end{array}$ & $\begin{array}{c}0.102 * * \\
{[2.512]}\end{array}$ & $\begin{array}{c}0.046 * * * \\
{[5.116]}\end{array}$ \\
\hline Log (CEO Delta) & $\begin{array}{c}-0.106^{* * *} \\
{[-4.198]}\end{array}$ & $\begin{array}{c}-0.130 * * * \\
{[-3.948]}\end{array}$ & $\begin{array}{c}-0.148 * * * \\
{[-3.732]}\end{array}$ & $\begin{array}{c}-0.093^{* * *} \\
{[-4.180]}\end{array}$ & $\begin{array}{c}-0.005 \\
{[-0.976]}\end{array}$ \\
\hline $\log (C E O$ Vega $)$ & $\begin{array}{c}0.005 \\
{[0.620]}\end{array}$ & $\begin{array}{c}0.013 \\
{[1.350]}\end{array}$ & $\begin{array}{c}0.017 \\
{[1.459]}\end{array}$ & $\begin{array}{c}0.005 \\
{[0.937]}\end{array}$ & $\begin{array}{c}0.001 \\
{[0.321]}\end{array}$ \\
\hline Observations & 5,707 & 5,707 & 5,707 & 5,707 & 5,707 \\
\hline R-squared & 0.446 & 0.462 & 0.425 & 0.397 & 0.379 \\
\hline \multicolumn{6}{|c|}{ Panel B: Controlling for CEO Confidence Options } \\
\hline General Ability Index & $\begin{array}{c}0.129 * * * \\
{[2.890]}\end{array}$ & $\begin{array}{c}0.169 * * * \\
{[2.979]}\end{array}$ & $\begin{array}{c}0.226 * * * \\
{[3.347]}\end{array}$ & $\begin{array}{l}0.088 * * \\
{[2.224]}\end{array}$ & $\begin{array}{c}0.044 * * * \\
{[4.786]}\end{array}$ \\
\hline CEO Confidence Options & $\begin{array}{c}0.084 \\
{[1.197]}\end{array}$ & $\begin{array}{l}0.159 * \\
{[1.733]}\end{array}$ & $\begin{array}{c}0.165 \\
{[1.468]}\end{array}$ & $\begin{array}{l}0.102 * \\
{[1.719]}\end{array}$ & $\begin{array}{c}-0.003 \\
{[-0.213]}\end{array}$ \\
\hline Observations & 6,895 & 6,895 & 6,895 & 6,895 & 6,895 \\
\hline R-squared & 0.437 & 0.459 & 0.422 & 0.391 & 0.370 \\
\hline \multicolumn{6}{|c|}{ Panel C: Controlling CEO Confidence Press } \\
\hline General Ability Index & $\begin{array}{c}0.119 * * * \\
{[2.700]}\end{array}$ & $\begin{array}{c}0.146 * * \\
{[2.576]}\end{array}$ & $\begin{array}{c}0.206 * * * \\
{[3.003]}\end{array}$ & $\begin{array}{l}0.072 * \\
{[1.920]}\end{array}$ & $\begin{array}{c}0.039 * * * \\
{[4.037]}\end{array}$ \\
\hline CEO Confidence Press & $\begin{array}{c}0.310 * * \\
{[2.489]}\end{array}$ & $\begin{array}{c}0.342 * * \\
{[2.183]}\end{array}$ & $\begin{array}{c}0.468 * * \\
{[2.468]}\end{array}$ & $\begin{array}{c}0.257 * * \\
{[2.321]}\end{array}$ & $\begin{array}{c}0.043^{*} \\
{[1.938]}\end{array}$ \\
\hline Total Press Mention & $\begin{array}{c}0.015^{* * *} \\
{[5.340]}\end{array}$ & $\begin{array}{c}0.014^{* * *} \\
{[4.390]}\end{array}$ & $\begin{array}{c}0.020 * * * \\
{[5.194]}\end{array}$ & $\begin{array}{c}0.016^{* * *} \\
{[6.831]}\end{array}$ & $\begin{array}{l}0.001^{*} \\
{[1.680]}\end{array}$ \\
\hline Observations & 6,212 & 6,212 & 6,212 & 6,212 & 6,212 \\
\hline R-squared & 0.459 & 0.473 & 0.440 & 0.416 & 0.382 \\
\hline
\end{tabular}




\section{Table 11}

\section{Innovation and General Managerial Ability: Innovative versus Non-innovative Industries}

This table presents estimates of ordinary least squares (OLS) panel regressions of the number of patents (Patents), number of citations (Citations), and innovation diversity (Innovative Diversity) on the General Ability Index and firm-level control variables. An industry is classified as innovative if the average $Q$ Citation for the industry is above the median $Q$ Citations across all industries in a given year. The sample consists of EXECUCOMP firms for which chief executive officer (CEO) profile data are available from BoardEx and operate in the same four-digit SIC industries as the firms included in the NBER patent database in the 1993-2003 period. CEOs with tenure below five years are omitted. Financial and utility firms are omitted. The regressions include the same firm-level control variables as in Table 4 (coefficients not shown). Regressions also include industry-year dummies. Variable definitions are provided in Table A1 in the Appendix. Robust $t$-statistics adjusted for firm-level clustering are reported in brackets. , , and ${ }^{* * *}$ indicates significance at the $10 \%, 5 \%$ and $1 \%$ levels respectively.

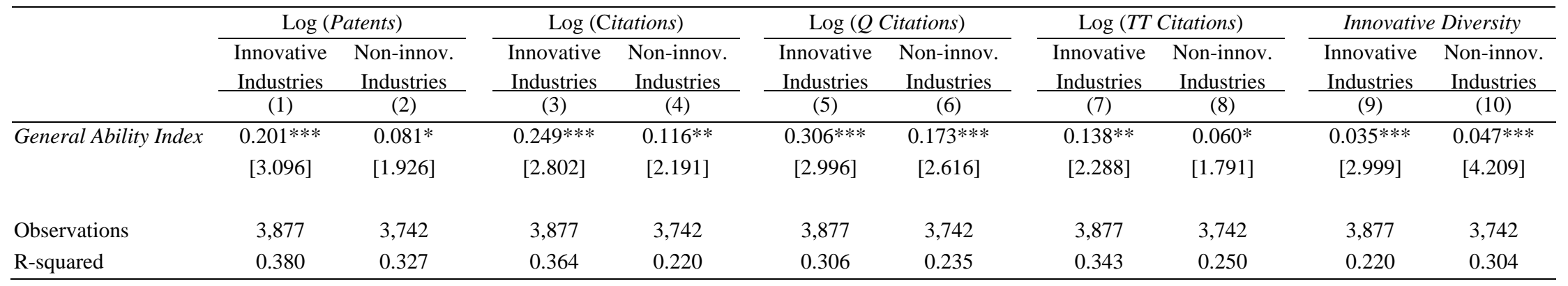




\section{Table 12}

\section{Innovation and General Managerial Ability: Controlling for R\&D Levels}

This table presents estimates of ordinary least squares (OLS) panel regressions of the number of patents (Patents), number of citations (Citations), and innovation diversity (Innovative Diversity) on the General Ability Index and firm-level control variables. The sample consists of EXECUCOMP firms for which chief executive officer (CEO) profile data are available from BoardEx and operate in the same four-digit SIC industries as the firms included in the NBER patent database in the 1993-2003 period. CEOs with tenure below five years are omitted. Financial and utility firms are omitted. The regressions include the same firm-level control variables as in Table 4 (coefficients not shown). Regressions also include industry-year dummies. Variable definitions are provided in Table A1 in the Appendix. Robust $t$-statistics adjusted for firm-level clustering are reported in brackets. ${ }^{*},{ }^{* *}$, and ${ }^{* * *}$ indicates significance at the $10 \%, 5 \%$ and $1 \%$ levels respectively.

\begin{tabular}{|c|c|c|c|c|c|}
\hline & Log (Patents) & $\begin{array}{c}\text { Log } \\
\text { (Citations) }\end{array}$ & $\begin{array}{c}\text { Log } \\
\text { (Q Citations) } \\
\end{array}$ & $\begin{array}{c}\text { Log } \\
\text { (TT Citations) }\end{array}$ & $\begin{array}{c}\text { Innovative } \\
\text { Diversity }\end{array}$ \\
\hline & $(1)$ & $(2)$ & $(3)$ & $(4)$ & $(5)$ \\
\hline \multicolumn{6}{|c|}{ Panel A: $R \& D$} \\
\hline \multirow[t]{2}{*}{ General Ability Index } & $0.090 * *$ & $0.117 * *$ & $0.162 * * *$ & 0.057 & $0.034 * * *$ \\
\hline & [2.284] & [2.282] & [2.681] & [1.576] & [4.125] \\
\hline \multirow[t]{2}{*}{$\log (R \& D)$} & $11.576^{* * *}$ & $14.721^{* * *}$ & $18.055^{* * *}$ & $9.537 * * *$ & $1.823 * * *$ \\
\hline & [11.865] & {$[11.222]$} & [11.594] & [10.533] & [10.019] \\
\hline Observations & 7,619 & 7,619 & 7,619 & 7,619 & 7,619 \\
\hline R-squared & 0.493 & 0.501 & 0.472 & 0.440 & 0.408 \\
\hline \multicolumn{6}{|c|}{ Panel B: R\&D Stock } \\
\hline \multirow[t]{2}{*}{ General Ability Index } & $0.109 * * *$ & $0.145^{* * *}$ & $0.195 * * *$ & $0.073 * *$ & $0.037 * * *$ \\
\hline & {$[2.718]$} & {$[2.767]$} & [3.140] & [1.990] & {$[4.463]$} \\
\hline \multirow[t]{2}{*}{$R \& D$ Stock } & $1.657 * * *$ & $1.857 * * *$ & $2.403 * * *$ & $1.363 * * *$ & $0.232 * * *$ \\
\hline & {$[9.744]$} & [8.613] & [8.955] & [7.986] & [8.233] \\
\hline Observations & 7,619 & 7,619 & 7,619 & 7,619 & 7,619 \\
\hline R-squared & 0.480 & 0.481 & 0.454 & 0.428 & 0.393 \\
\hline
\end{tabular}




\section{Appendix}

Table A1

Variable Definitions

\begin{tabular}{|c|c|}
\hline Variable & Description \\
\hline \multicolumn{2}{|r|}{ Panel A: Innovation Measures } \\
\hline$R \& D$ & Research and development expenses divided by total assets (Compustat XRD / AT). \\
\hline Patents & Number of patent applications by a firm in a given year (NBER patent database). \\
\hline Citations & Total number of citations subsequently received by the set of patents that a firm applied for in a given year (NBER patent database). \\
\hline Q Citations & $\begin{array}{l}\text { Sum of the adjusted patent citations across all patents that a firm applied for in a given year; the weighting index is from Hall, Jaffe, } \\
\text { and Trajtenberg }(2001,2005) \text { (NBER patent database). }\end{array}$ \\
\hline TT Citations & $\begin{array}{l}\text { Sum of the adjusted citation count across all patents that a firm applied for in a given year; the scaling is based on the average citation } \\
\text { count of all patents in the same two-digit technology class and year (NBER patent database). }\end{array}$ \\
\hline Innovative Diversity & $\begin{array}{l}\text { One minus the Herfindahl index of the patent portfolio (patents filed by the firm in the previous five years) using two-digit } \\
\text { technological classes (NBER patent database). }\end{array}$ \\
\hline Search Distance & $\begin{array}{l}\text { Degree of difference between the current distribution of a firm's patent portfolio across two-digit technological classes and the } \\
\text { analogous distribution calculated for new patents and adjusted for the expected degree of knowledge spillovers expected between } \\
\text { patent classes (NBER patent database). }\end{array}$ \\
\hline Originality Index & $\begin{array}{l}\text { One minus the Herfindahl index of the citations made by the patent portfolio (patents filed by the firm in the previous five years) } \\
\text { based on two-digit technology classes (NBER patent database). }\end{array}$ \\
\hline Generality Index & $\begin{array}{l}\text { One minus the Herfindahl index of the citations received by the patent portfolio (patents filed by the firm in the previous five years) } \\
\text { based on two-digit technology classes (NBER patent database). }\end{array}$ \\
\hline Exploitative Ratio 80 & $\begin{array}{l}\text { Number of exploitative patents filed in a given year divided by the number of all patents filed by the firm in the same year; a patent is } \\
\text { classified as exploitative if at least } 80 \% \text { of its citations are based on existing knowledge (NBER patent database). }\end{array}$ \\
\hline Exploitative Ratio 60 & $\begin{array}{l}\text { Number of exploitative patents filed in a given year divided by the number of all patents filed by the firm in the same year; a patent is } \\
\text { classified as exploitative if at least } 60 \% \text { of its citations are based on existing knowledge (NBER patent database). }\end{array}$ \\
\hline Exploratory Ratio 80 & $\begin{array}{l}\text { Number of exploratory patents filed in a given year divided by the number of all patents filed by the firm in the same year; a patent is } \\
\text { classified as exploratory if at least } 80 \% \text { of its citations are based on new knowledge (NBER patent database). }\end{array}$ \\
\hline Exploratory Ratio 60 & $\begin{array}{l}\text { Number of exploratory patents filed in a given year divided by the number of all patents filed by the firm in the same year; a patent is } \\
\text { classified as exploratory if at least } 60 \% \text { of its citations are based on new knowledge (NBER patent database). }\end{array}$ \\
\hline \multicolumn{2}{|r|}{ Panel B: CEO Characteristics } \\
\hline General Ability Index & $\begin{array}{l}\text { First factor of applying principal components analysis to five proxies of general managerial ability: past Number of Positions, Number } \\
\text { of Firms, Number of Industries, CEO Experience Dummy, and Conglomerate Experience Dummy (BoardEx). }\end{array}$ \\
\hline CEO Delta & $\begin{array}{l}\text { Dollar change in a CEO's stock and option portfolio for a 1\% change in stock price using the one-year approximation method of Core } \\
\text { and Guay (2002) (EXECUCOMP). }\end{array}$ \\
\hline
\end{tabular}


CEO Vega

CEO Confidence Options

CEO Confidence Press

Total Press Mentions

CEO Tenure

CEO Age

External Hire Dummy

MBA Dummy

CEO-Chair Dummy

\begin{tabular}{|c|c|}
\hline \multicolumn{2}{|r|}{ Panel C: Firm Characteristics } \\
\hline Sales & Sales in thousands of dollars (Compustat SALE). \\
\hline$P P E$ & Net property, plant, and equipment divided by sales (Compustat (PPENT / SALE)). \\
\hline Stock Return & Annual stock return (Compustat (PRCC_F(t) / AJEX(t) + DVPSX_F(t) / AJEX(t)) / (PRCC_F(t-1) / AJEX_F(t-1))). \\
\hline Institutional Ownership & Shares held by institutional investors as a fraction of shares outstanding (Thomson CDA/Spectrum 13F Holdings). \\
\hline Leverage & Total debt, defined as debt in current liabilities plus long-term debt, divided by total assets (Compustat (DLC + DLTT) / AT). \\
\hline Market-to-Book & Assets plus market value of equity minus book value of equity divided by assets (Compustat (AT + CSHO $\times$ PRCC_F - CEQ) $/$ AT)). \\
\hline ROA & Earnings before interest and taxes divided by total assets (Compustat EBIT / AT). \\
\hline Volatility & Annualized standard deviation of monthly stock returns (CRSP). \\
\hline Diversification Dummy & Dummy variable that takes a value of one if a firm has more than one business segment, and zero otherwise (Compustat). \\
\hline Cash & Cash and short-term investments divided by total assets (Compustat CHE / AT). \\
\hline CAPEX & Capital expenditures divided by total assets (CAPX / AT). \\
\hline Firm Age & Number of years since a firm listed its shares (CRSP). \\
\hline Board Size & Number of directors (IRRC). \\
\hline Board Independence & Ratio of number of independent directors to number of directors (IRRC). \\
\hline Industry Sales Herfindahl & Herfindahl index calculated as the sum of squared market shares of firms' sales (Compustat SALE) at the two-digit SIC industry level. \\
\hline Governance Index & Governance index of Gompers, Ishii, and Metrick (2003), which is based on 24 antitakeover provisions (IRRC). \\
\hline \multicolumn{2}{|r|}{ Panel D: Instruments } \\
\hline Enforcement Index & Noncompetition enforcement index (Garmaise (2009)) \\
\hline In-State Competition & $\begin{array}{l}\text { Fraction of total industry sales (excluding those of the firm itself) generated by in-state competitors, i.e. Compustat firms with the } \\
\text { same four-digit SIC and with headquarters in the same state. }\end{array}$ \\
\hline
\end{tabular}

Dollar change in a CEO's option holdings for a 1\% change in stock return volatility using the one-year approximation method of Core and Guay (2002) (EXECUCOMP).

Dummy variable that takes a value of one if a CEO postpones the exercise of vested options that are at least $67 \%$ in the money, and zero otherwise (EXECUCOMP).

Dummy variable takes the value of one when the number of "confident” articles for a CEO is greater than the number of "cautious" articles, and zero otherwise (Factiva).

Number of press articles mentioning the CEO (Factiva).

Number of years as CEO in the current position (BoardEx).

Age of CEO in years (BoardEx).

Dummy variable that takes a value of one if CEO was hired from outside the firm, and zero otherwise (BoardEx).

Dummy variable that takes a value of one if CEO has a MBA degree, and zero otherwise (BoardEx).

Dummy variable that takes a value of one if CEO is also chair of the board, and zero otherwise (BoardEx).

Sales in thousands of dollars (Compustat SALE).

Shares held by institutional investors as a fraction of shares outstanding (Thomson CDA/Spectrum 13F Holdings).

Assets plus market value of equity minus book value of equity divided by assets (Compustat (AT + CSHO × PRCC_F - CEQ) / AT))

Earnings before interest and taxes divided by total assets (Compustat EBIT / AT).

Annualized standard deviation of monthly stock returns (CRSP).

Capital expenditures divided by total assets (CAPX / AT). 


\title{
Internet Appendix for “Do General Managerial Skills Spur Innovation?”
}

\author{
Cláudia Custódio, Arizona State University \\ Miguel A. Ferreira, Nova School of Business and Economics \\ Pedro Matos, University of Virginia - Darden School of Business
}




\section{Table IA.I}

\section{Innovation and General Managerial Ability: Sample of CEOs}

This table presents estimates of ordinary least squares (OLS) panel regressions of the number of patents (Patents), number of citations (Citations), and innovation diversity (Innovative Diversity) on the General Ability Index and firm-level control variables. The sample consists of EXECUCOMP firms for which chief executive officer (CEO) profile data are available from BoardEx and operate in the same four-digit SIC industries as the firms included in the NBER patent database in the 1993-2003 period. CEOs with tenure below two years (Panel A) or tenure below three years (Panel B) are omitted. Financial and utility firms are omitted. Regressions include industry-year dummies. Variable definitions are provided in Table A1 in the Appendix. Robust $t$-statistics adjusted for firm-level clustering are reported in brackets. ${ }^{*},{ }^{* *}$, and ${ }^{* * *}$ indicates significance at the $10 \%, 5 \%$ and $1 \%$ levels respectively.

\begin{tabular}{|c|c|c|c|c|c|}
\hline & Log (Patents) & Log (Citations) & $\begin{array}{c}\text { Log } \\
\text { (Q Citations) }\end{array}$ & $\begin{array}{c}\text { Log } \\
\text { (TT Citations) }\end{array}$ & $\begin{array}{c}\text { Innovative } \\
\text { Diversity }\end{array}$ \\
\hline & (1) & $(2)$ & (3) & (4) & (5) \\
\hline \multicolumn{6}{|c|}{ Panel A: Observations with CEO Tenure $<2$ years Omitted } \\
\hline \multirow[t]{2}{*}{ General Ability Index } & $0.108 * * *$ & $0.148 * * *$ & $0.195 * * *$ & $0.075^{* *}$ & $0.034 * * *$ \\
\hline & [3.086] & [3.217] & [3.554] & [2.395] & [4.603] \\
\hline \multirow[t]{2}{*}{ Log (Sales) } & $0.508 * * *$ & $0.583 * * *$ & $0.675 * * *$ & $0.399 * * *$ & $0.068 * * *$ \\
\hline & {$[16.214]$} & {$[15.200]$} & {$[15.216]$} & {$[14.360]$} & [14.253] \\
\hline \multirow[t]{2}{*}{$\log (P P E)$} & $0.194 * * *$ & $0.184 * * *$ & $0.220 * * *$ & $0.144 * * *$ & $0.024 * * *$ \\
\hline & [5.313] & [3.868] & [3.847] & {$[4.545]$} & [3.252] \\
\hline Observations & 9,503 & 9,503 & 9,503 & 9,503 & 9,503 \\
\hline R-squared & 0.412 & 0.426 & 0.392 & 0.364 & 0.355 \\
\hline \multicolumn{6}{|c|}{ Panel B: Observations with CEO Tenure $<3$ years Omitted } \\
\hline \multirow[t]{2}{*}{ General Ability Index } & $0.112 * * *$ & $0.148 * * *$ & $0.198 * * *$ & $0.075^{* *}$ & $0.035 * * *$ \\
\hline & [3.062] & [3.092] & [3.481] & [2.300] & [4.559] \\
\hline \multirow[t]{2}{*}{ Log (Sales) } & $0.510 * * *$ & $0.587 * * *$ & $0.680 * * *$ & $0.404 * * *$ & $0.068 * * *$ \\
\hline & [15.897] & [14.940] & [14.991] & [14.234] & [13.879] \\
\hline \multirow[t]{2}{*}{$\log (P P E)$} & $0.197 * * *$ & $0.188^{* * *}$ & $0.223^{* * *}$ & $0.143^{* * *}$ & $0.025^{* * *}$ \\
\hline & [5.319] & [3.910] & [3.862] & [4.439] & [3.280] \\
\hline Observations & 9,070 & 9,070 & 9,070 & 9,070 & 9,070 \\
\hline R-squared & 0.413 & 0.427 & 0.394 & 0.365 & 0.356 \\
\hline
\end{tabular}




\section{Table IA.II}

\section{Innovation and General Managerial Ability: Poisson Model}

This table presents estimates of Poisson panel regressions of the number of patents (Patents) and number of citations (Citations) on the General Ability Index and firm-level control variables. The sample consists of EXECUCOMP firms for which chief executive officer (CEO) profile data are available from BoardEx and operate in the same four-digit SIC industries as the firms included in the NBER patent database in the 1993-2003 period. CEOs with tenure below five years are omitted. Financial and utility firms are omitted. Regressions include industry and year dummies. Variable definitions are provided in Table A1 in the Appendix. Robust $t$-statistics adjusted for firm-level clustering are reported in brackets. ${ }^{*},{ }^{* *}$, and ${ }^{* * *}$ indicates significance at the $10 \%, 5 \%$ and $1 \%$ levels respectively.

\begin{tabular}{lcccc}
\hline & Patents & Citations & Q Citations & TT Citations \\
\cline { 2 - 5 } & $(1)$ & $(2)$ & $(3)$ & $(4)$ \\
\hline General Ability Index & $0.121^{* * *}$ & $0.077^{* *}$ & $0.069^{*}$ & $0.086^{* *}$ \\
& {$[4.130]$} & {$[1.998]$} & {$[1.886]$} & {$[2.383]$} \\
Log (Sales) & $0.972^{* * *}$ & $0.948^{* * *}$ & $0.964^{* * *}$ & $0.875^{* * *}$ \\
& {$[55.728]$} & {$[49.086]$} & {$[53.797]$} & {$[48.715]$} \\
$\log (P P E)$ & $0.786^{* * *}$ & $0.745^{* * *}$ & $0.783^{* * *}$ & $0.665^{* * *}$ \\
& {$[9.943]$} & {$[7.042]$} & {$[7.669]$} & {$[7.167]$} \\
& & & & \\
Observations & 7,619 & 7,619 & 7,619 & 7,619 \\
\hline
\end{tabular}




\section{Table IA.III}

\section{Patent Citations per Patent and General Managerial Ability}

This table presents estimates of ordinary least squares (OLS) and Negative Binomial panel regressions of the number of citations per patent (Citations) on the General Ability Index and firm-level control variables. The sample consists of EXECUCOMP firms for which chief executive officer (CEO) profile data are available from BoardEx and operate in the same four-digit SIC industries as the firms included in the NBER patent database in the 1993-2003 period. CEOs with tenure below five years are omitted. Financial and utility firms are omitted. Regressions include industry-year dummies. Variable definitions are provided in Table A1 in the Appendix. Robust $t$-statistics adjusted for firm-level clustering are reported in brackets. ${ }^{* * *},{ }^{* *}$, and ${ }^{* * *}$ indicates significance at the $10 \%, 5 \%$ and $1 \%$ levels respectively.

\begin{tabular}{|c|c|c|c|c|c|c|}
\hline & \multicolumn{3}{|c|}{ OLS } & \multicolumn{3}{|c|}{ Negative Binomial } \\
\hline & Log (Citations) & $\begin{array}{c}\text { Log } \\
\text { (Q Citations) }\end{array}$ & $\begin{array}{c}\text { Log } \\
\text { (TT Citations) }\end{array}$ & Citations & Q Citations & TT Citations \\
\hline & $(1)$ & $(3)$ & (5) & $(2)$ & (4) & (6) \\
\hline \multirow[t]{2}{*}{ General Ability Index } & $0.174^{* * *}$ & $0.232 * * *$ & $0.094^{* *}$ & $0.255^{* * *}$ & $0.294 * * *$ & $0.189 * * *$ \\
\hline & [3.177] & [3.564] & {$[2.475]$} & [3.298] & [3.663] & {$[2.662]$} \\
\hline \multirow[t]{2}{*}{ Log (Sales) } & $0.588 * * *$ & $0.683^{* * *}$ & $0.408 * * *$ & $0.727 * * *$ & $0.717 * * *$ & $0.622 * * *$ \\
\hline & [13.847] & {$[13.906]$} & [13.318] & [13.876] & {$[13.791]$} & [13.317] \\
\hline \multirow[t]{2}{*}{$\log (P P E)$} & $0.166^{* * *}$ & $0.194 * * *$ & $0.130^{* * *}$ & $0.264^{* * *}$ & $0.257^{* * *}$ & $0.223 * *$ \\
\hline & [3.191] & [3.116] & [3.717] & [2.704] & [2.597] & [2.531] \\
\hline Number of observations & 7,619 & 7,619 & 7,619 & 7,619 & 7,619 & 7,619 \\
\hline R-squared & 0.446 & 0.413 & 0.382 & & & \\
\hline
\end{tabular}




\section{Table IA.IV}

\section{Innovation and General Managerial Ability: Additional Firm-Level Controls}

This table presents estimates of ordinary least squares (OLS) panel regressions of the number of patents (Patents), number of citations (Citations), and innovation diversity (Innovative Diversity) on the General Ability Index and firm-level control variables. The sample consists of EXECUCOMP firms for which chief executive officer (CEO) profile data are available from BoardEx and operate in the same four-digit SIC industries as the firms included in the NBER patent database in the 1993-2003 period. CEOs with tenure below five years are omitted. Financial and utility firms are omitted. Regressions include industry-year dummies. Variable definitions are provided in Table A1 in the Appendix. Robust $t$-statistics adjusted for firm-level clustering are reported in brackets. ${ }^{*}, *$, and ${ }^{* * *}$ indicates significance at the $10 \%, 5 \%$ and $1 \%$ levels respectively.

\begin{tabular}{|c|c|c|c|c|c|}
\hline & Log (Patents) & Log (Citations) & $\begin{array}{c}\text { Log } \\
\text { (Q Citations) }\end{array}$ & $\begin{array}{c}\text { Log } \\
\text { (TT Citations) }\end{array}$ & $\begin{array}{c}\text { Innovative } \\
\text { Diversity }\end{array}$ \\
\hline & $(1)$ & $(2)$ & (3) & (4) & $(5)$ \\
\hline \multirow[t]{2}{*}{ General Ability Index } & $0.109 * *$ & $0.127 * *$ & $0.172 * *$ & $0.080^{*}$ & $0.030 * * *$ \\
\hline & {$[2.341]$} & {$[2.231]$} & {$[2.450]$} & [1.882] & {$[2.978]$} \\
\hline \multirow[t]{2}{*}{ Log (Sales) } & $0.526 * * *$ & $0.581 * * *$ & $0.686^{* * *}$ & $0.456 * * *$ & $0.048 * * *$ \\
\hline & {$[11.710]$} & [11.064] & [10.685] & {$[10.794]$} & [6.192] \\
\hline \multirow[t]{2}{*}{$\log (P P E)$} & $0.196 * * *$ & $0.184 * * *$ & $0.217 * * *$ & $0.147 * * *$ & $0.026 * *$ \\
\hline & [4.174] & [3.199] & [3.041] & [3.485] & {$[2.560]$} \\
\hline \multirow[t]{2}{*}{ Stock Return } & $0.176^{* * *}$ & $0.245^{* * *}$ & $0.284 * * *$ & $0.171^{* * *}$ & 0.006 \\
\hline & [4.479] & [4.498] & [4.208] & [4.333] & [0.783] \\
\hline \multirow[t]{2}{*}{ Institutional Ownership } & $-0.779 * * *$ & $-0.735 * *$ & $-0.905 * *$ & $-0.786 * * *$ & -0.033 \\
\hline & {$[-3.055]$} & {$[-2.403]$} & {$[-2.334]$} & {$[-3.492]$} & {$[-0.644]$} \\
\hline \multirow[t]{2}{*}{ Volatility } & $2.454 * * *$ & $3.101 * * *$ & $3.683 * * *$ & $2.161 * * *$ & $0.314^{* *}$ \\
\hline & [3.753] & [3.835] & [3.612] & [3.573] & {$[2.477]$} \\
\hline \multirow[t]{2}{*}{ Firm Age } & $0.013^{* * *}$ & $0.014 * * *$ & $0.017 * * *$ & $0.008 * * *$ & $0.003^{* * *}$ \\
\hline & [4.298] & {$[4.062]$} & {$[4.081]$} & [3.283] & [4.993] \\
\hline \multirow[t]{2}{*}{ Diversification Dummy } & -0.089 & -0.122 & -0.141 & $-0.130 *$ & $0.029 *$ \\
\hline & {$[-1.074]$} & {$[-1.187]$} & {$[-1.086]$} & {$[-1.724]$} & {$[1.676]$} \\
\hline \multirow[t]{2}{*}{ Board Size } & 0.008 & 0.008 & 0.007 & 0.001 & -0.001 \\
\hline & {$[0.417]$} & {$[0.332]$} & {$[0.260]$} & {$[0.090]$} & {$[-0.130]$} \\
\hline \multirow[t]{2}{*}{ Board Independence } & $0.894 * * *$ & $1.065^{* * *}$ & $1.396^{* * *}$ & $0.760 * * *$ & $0.184^{* * *}$ \\
\hline & [3.633] & [3.531] & [3.679] & [3.590] & [3.624] \\
\hline \multirow[t]{2}{*}{ Industry Sales Herfindahl } & $-1.612 *$ & $-1.977^{*}$ & $-2.412 *$ & $-1.405^{* *}$ & -0.083 \\
\hline & {$[-1.721]$} & {$[-1.886]$} & {$[-1.905]$} & {$[-2.003]$} & {$[-0.528]$} \\
\hline \multirow[t]{2}{*}{ Governance Index } & -0.026 & -0.036 & -0.030 & $-0.033^{*}$ & 0.001 \\
\hline & {$[-1.322]$} & {$[-1.502]$} & {$[-1.013]$} & {$[-1.900]$} & [0.285] \\
\hline Observations & 4,431 & 4,431 & 4,431 & 4,431 & 4,431 \\
\hline R-squared & 0.490 & 0.512 & 0.473 & 0.448 & 0.403 \\
\hline
\end{tabular}




\section{Table IA.V}

\section{Innovation and General Managerial Ability: Additional CEO Controls}

This table presents estimates of ordinary least squares (OLS) panel regressions of the number of patents (Patents), number of citations (Citations), and innovation diversity (Innovative Diversity) on the General Ability Index and firm-level control variables. The sample consists of EXECUCOMP firms for which chief executive officer (CEO) profile data are available from BoardEx and operate in the same four-digit SIC industries as the firms included in the NBER patent database in the 1993-2003 period. CEOs with tenure below five years are omitted. Financial and utility firms are omitted. Regressions include industry-year dummies. Variable definitions are provided in Table A1 in the Appendix. Robust $t$-statistics adjusted for firm-level clustering are reported in brackets. ${ }^{*},{ }^{* *}$, and ${ }^{* * *}$ indicates significance at the $10 \%, 5 \%$ and $1 \%$ levels respectively.

\begin{tabular}{|c|c|c|c|c|c|}
\hline & Log (Patents) & Log (Citations) & $\begin{array}{c}\text { Log } \\
\text { (Q Citations) }\end{array}$ & $\begin{array}{c}\text { Log } \\
\text { (TT Citations) }\end{array}$ & $\begin{array}{c}\text { Innovative } \\
\text { Diversity }\end{array}$ \\
\hline & $(1)$ & $(2)$ & (3) & $(4)$ & (5) \\
\hline \multirow[t]{2}{*}{ General Ability Index } & $0.095 * *$ & $0.121^{* *}$ & $0.174 * *$ & 0.066 & $0.035 * * *$ \\
\hline & [2.052] & [2.058] & [2.460] & [1.602] & [3.516] \\
\hline \multirow[t]{2}{*}{ Log (Sales) } & $0.534 * * *$ & $0.600 * * *$ & $0.705^{* * *}$ & $0.432 * * *$ & $0.066^{* * *}$ \\
\hline & {$[14.184]$} & {$[13.258]$} & [13.338] & {$[12.802]$} & {$[11.262]$} \\
\hline \multirow[t]{2}{*}{$\log (P P E)$} & $0.200 * * *$ & $0.189 * * *$ & $0.223 * * *$ & $0.145^{* * *}$ & $0.025^{* * *}$ \\
\hline & [4.460] & [3.334] & [3.256] & [3.633] & [2.657] \\
\hline \multirow[t]{2}{*}{ Stock Return } & $0.109 * * *$ & $0.165^{* * *}$ & $0.177^{* * *}$ & $0.105^{* * *}$ & 0.002 \\
\hline & [3.359] & [3.555] & [3.068] & [3.220] & {$[0.246]$} \\
\hline \multirow[t]{2}{*}{ Institutional Ownership } & $-0.447 * *$ & -0.324 & -0.403 & $-0.390 * *$ & -0.038 \\
\hline & {$[-2.168]$} & {$[-1.250]$} & {$[-1.244]$} & {$[-2.175]$} & {$[-0.883]$} \\
\hline \multirow[t]{2}{*}{ CEO Tenure } & 0.002 & 0.003 & 0.005 & 0.003 & -0.001 \\
\hline & [0.294] & {$[0.416]$} & [0.473] & {$[0.516]$} & {$[-0.708]$} \\
\hline \multirow[t]{2}{*}{ CEO Age } & -0.009 & -0.011 & -0.014 & $-0.012 * *$ & 0.001 \\
\hline & {$[-1.315]$} & {$[-1.279]$} & {$[-1.423]$} & {$[-2.007]$} & {$[0.508]$} \\
\hline \multirow[t]{2}{*}{ MBA Dummy } & $0.252 * * *$ & $0.304 * * *$ & $0.391 * * *$ & $0.212 * * *$ & $0.042 * *$ \\
\hline & {$[2.827]$} & {$[2.651]$} & {$[2.801]$} & {$[2.661]$} & {$[2.269]$} \\
\hline Observations & 6,082 & 6,082 & 6,082 & 6,082 & 6,082 \\
\hline R-squared & 0.452 & 0.479 & 0.439 & 0.408 & 0.372 \\
\hline
\end{tabular}




\section{Table IA.VI}

\section{Innovation and General Managerial Ability: Lagged Explanatory Variables}

This table presents estimates of ordinary least squares (OLS) panel regressions of the number of patents (Patents) and number of citations (Citations) on the General Ability Index and firm-level control variables. The sample consists of EXECUCOMP firms for which chief executive officer (CEO) profile data are available from BoardEx and operate in the same four-digit SIC industries as the firms included in the NBER patent database in the 1993-2003 period. CEOs with tenure below five years are omitted. Financial and utility firms are omitted. Regressions include industry-year dummies. Variable definitions are provided in Table A1 in the Appendix. Robust $t$-statistics adjusted for firm-level clustering are reported in brackets. ${ }^{*},{ }^{* *}$, and ${ }^{* * *}$ indicates significance at the $10 \%, 5 \%$ and $1 \%$ levels respectively.

\begin{tabular}{|c|c|c|c|c|c|}
\hline & Log (Patents) & Log (Citations) & $\begin{array}{c}\log \\
(Q \text { Citations) }\end{array}$ & $\begin{array}{c}\text { Log } \\
\text { (TT Citations) }\end{array}$ & $\begin{array}{c}\text { Innovative } \\
\text { Diversity }\end{array}$ \\
\hline & (1) & (2) & (3) & (4) & (5) \\
\hline \multicolumn{6}{|c|}{ Panel A: One-year Lag } \\
\hline \multirow[t]{2}{*}{ General Ability Index } & $0.138 * * *$ & $0.165^{* * * *}$ & $0.228 * * *$ & $0.093 * *$ & $0.041 * * *$ \\
\hline & [3.009] & [2.883] & [3.308] & [2.295] & [4.374] \\
\hline \multirow[t]{2}{*}{ Log (Sales) } & $0.516 * * *$ & $0.587 * * *$ & $0.690 * * *$ & $0.412 * * *$ & $0.069 * * *$ \\
\hline & [14.178] & [13.473] & [13.524] & [13.078] & [12.544] \\
\hline \multirow[t]{2}{*}{$\log (P P E)$} & $0.175^{* * *}$ & $0.161 * * *$ & $0.191 * * *$ & $0.127 * * *$ & $0.021 * *$ \\
\hline & [4.164] & [3.020] & [2.950] & [3.483] & [2.335] \\
\hline Observations & 6,339 & 6,339 & 6,339 & 6,339 & 6,339 \\
\hline R-squared & 0.432 & 0.458 & 0.422 & 0.388 & 0.371 \\
\hline \multicolumn{6}{|c|}{ Panel A: Three-year Lag } \\
\hline \multirow[t]{2}{*}{ General Ability Index } & $0.151^{* * *}$ & $0.164 * * *$ & $0.246 * * *$ & $0.105^{* *}$ & $0.039 * * *$ \\
\hline & {$[2.806]$} & [2.592] & [3.181] & [2.174] & {$[3.800]$} \\
\hline \multirow[t]{2}{*}{ Log (Sales) } & $0.522 * * *$ & $0.568 * * *$ & $0.688 * * *$ & $0.421 * * *$ & $0.070 * * *$ \\
\hline & [13.227] & [12.639] & [12.737] & [12.385] & {$[12.030]$} \\
\hline \multirow[t]{2}{*}{$\log (P P E)$} & $0.153 * * *$ & $0.125^{* *}$ & $0.153^{* *}$ & $0.105 * * *$ & $0.018^{*}$ \\
\hline & [3.307] & [2.243] & [2.198] & [2.652] & [1.806] \\
\hline Observations & 4,331 & 4,331 & 4,331 & 4,331 & 4,331 \\
\hline R-squared & 0.450 & 0.481 & 0.445 & 0.410 & 0.384 \\
\hline
\end{tabular}




\section{Table IA.VII}

\section{Changes in Innovation and Changes in General Managerial Ability}

This table presents estimates of ordinary least squares (OLS) panel regressions of changes in the number of patents (Patents) and number of citations (Citations) on changes in the General Ability Index and firm-level control variables. The sample consists of EXECUCOMP firms for which chief executive officer (CEO) profile data are available from BoardEx and operate in the same four-digit SIC industries as the firms included in the NBER patent database in the 1993-2003 period. CEOs with tenure below five years are omitted. Financial and utility firms are omitted. Regressions include industry-year dummies. Variable definitions are provided in Table A1 in the Appendix. Robust $t$-statistics adjusted for firm-level clustering are reported in brackets. ${ }^{*},{ }^{* *}$, and ${ }^{* * *}$ indicates significance at the $10 \%, 5 \%$ and $1 \%$ levels respectively.

\begin{tabular}{lcccc}
\hline & $\log ($ Patents $)$ & $\log ($ Citations $)$ & $\log ($ Q Citations $)$ & Log (TT Citations) \\
\cline { 2 - 5 } & $(1)$ & $(2)$ & $(3)$ & $(4)$ \\
\hline General Ability Index & $0.106^{* * *}$ & $0.111^{* *}$ & $0.126^{*}$ & $0.066^{*}$ \\
Log (Sales) & {$[2.970]$} & {$[2.039]$} & {$[1.819]$} & {$[1.884]$} \\
& $0.231^{* * *}$ & $0.341^{* * *}$ & $0.393^{* * *}$ & $0.176^{* * *}$ \\
$\log (P P E)$ & {$[6.320]$} & {$[5.814]$} & {$[5.010]$} & {$[4.338]$} \\
& $0.096^{* * *}$ & 0.051 & 0.051 & 0.014 \\
Observations & {$[3.345]$} & {$[1.023]$} & {$[0.797]$} & {$[0.439]$} \\
& & & & 6,267 \\
\hline
\end{tabular}




\section{Table IA.VIII}

\section{Innovation and General Managerial Ability Dummy Variable}

This table presents estimates of ordinary least squares (OLS) panel regressions of the number of patents (Patents), number of citations (Citations), and innovation diversity (Innovative Diversity) on the General Ability Index Dummy and firm-level control variables. The General Ability Index Dummy takes the value of one when a top executive has a General Ability Index above the median in a given year. The sample consists of EXECUCOMP firms for which chief executive officer (CEO) profile data are available from BoardEx and operate in the same four-digit SIC industries as the firms included in the NBER patent database in the 1993-2003 period. CEOs with tenure below five years are omitted. Financial and utility firms are omitted. Regressions include industry-year dummies. Variable definitions are provided in Table A1 in the Appendix. Robust $t$-statistics adjusted for firm-level clustering are reported in brackets. ${ }^{*},{ }^{* *}$, and ${ }^{* * *}$ indicates significance at the $10 \%, 5 \%$ and $1 \%$ levels respectively.

\begin{tabular}{|c|c|c|c|c|c|}
\hline & Log (Patents) & Log (Citations) & $\begin{array}{c}\text { Log } \\
\text { (Q Citations) }\end{array}$ & $\begin{array}{c}\text { Log } \\
\text { (TT Citations) }\end{array}$ & $\begin{array}{c}\text { Innovative } \\
\text { Diversity }\end{array}$ \\
\hline & (1) & (2) & (3) & (4) & (5) \\
\hline \multirow[t]{2}{*}{ General Ability Index Dummy } & $0.197 * * *$ & $0.256 * * *$ & $0.345^{* * *}$ & $0.116 *$ & $0.068 * * *$ \\
\hline & [2.595] & [2.589] & [2.884] & [1.769] & [4.404] \\
\hline \multirow[t]{2}{*}{ Log (Sales) } & $0.521 * * *$ & $0.597 * * *$ & $0.695 * * *$ & $0.415^{* * *}$ & $0.069 * * *$ \\
\hline & [14.892] & [14.061] & [14.194] & [13.439] & [13.099] \\
\hline \multirow[t]{2}{*}{$\log (P P E)$} & $0.184 * * *$ & $0.170 * * *$ & $0.199 * * *$ & $0.132 * * *$ & $0.023^{* * *}$ \\
\hline & {$[4.604]$} & {$[3.274]$} & {$[3.206]$} & [3.799] & {$[2.740]$} \\
\hline Observations & 7,619 & 7,619 & 7,619 & 7,619 & 7,619 \\
\hline R-squared & 0.428 & 0.445 & 0.412 & 0.380 & 0.365 \\
\hline
\end{tabular}




\section{Table IA.IX}

\section{Innovation and General Managerial Ability Components}

This table presents estimates of ordinary least squares (OLS) panel regressions of the number of patents (Patents), number of citations (Citations), and innovation diversity (Innovative Diversity) on the General Ability Index components and firm-level control variables. The sample consists of EXECUCOMP firms for which chief executive officer (CEO) profile data are available from BoardEx and operate in the same four-digit SIC industries as the firms included in the NBER patent database in the 19932003 period. CEOs with tenure below five years are omitted. Financial and utility firms are omitted. Regressions include industry-year dummies. Variable definitions are provided in Table A1 in the Appendix. Robust $t$-statistics adjusted for firm-level clustering are reported in brackets. ${ }^{*}, *$, and ${ }^{* * *}$ indicates significance at the $10 \%, 5 \%$ and $1 \%$ levels respectively.

\begin{tabular}{|c|c|c|c|c|c|}
\hline & \multicolumn{5}{|c|}{ Log(Patents) } \\
\hline & $(1)$ & $(2)$ & (3) & (4) & (5) \\
\hline \multirow[t]{2}{*}{ Number of Positions } & $0.050 * * *$ & & & & \\
\hline & [3.642] & & & & \\
\hline \multirow[t]{2}{*}{ Number of Firms } & & $0.073 * * *$ & & & \\
\hline & & [3.163] & & & \\
\hline \multirow[t]{2}{*}{ Number of Industries } & & & $0.070^{* * *}$ & & \\
\hline & & & [2.688] & & \\
\hline \multirow[t]{2}{*}{ CEO Experience Dummy } & & & & 0.040 & \\
\hline & & & & {$[0.496]$} & \\
\hline \multirow[t]{2}{*}{ Conglomerate Experience Dummy } & & & & & 0.091 \\
\hline & & & & & {$[1.131]$} \\
\hline \multirow[t]{2}{*}{ Log (Sales) } & $0.496 * * *$ & $0.519 * * *$ & $0.522 * * *$ & $0.534 * * *$ & $0.538 * * *$ \\
\hline & [14.003] & [15.098] & [15.107] & [15.829] & [16.036] \\
\hline \multirow[t]{2}{*}{$\log (P P E)$} & $0.171^{* * *}$ & $0.182 * * *$ & $0.184 * * *$ & $0.187 * * *$ & $0.188 * * *$ \\
\hline & [4.231] & [4.555] & {$[4.576]$} & {$[4.702]$} & [4.717] \\
\hline Observations & 6,757 & 6,757 & 6,757 & 6,757 & 6,757 \\
\hline R-squared & 0.479 & 0.481 & 0.460 & 0.405 & 0.477 \\
\hline
\end{tabular}

